\title{
The evolution of BDNF is defined by strict purifying selection and prodomain spatial coevolution, but what does it mean for human brain disease?
}

\author{
Alexander G Lucaci ${ }^{1, *}$, Michael J Notaras ${ }^{2, *}$, Sergei L Kosakovsky Pond ${ }^{1}$, Dilek Colak ${ }^{2,3}$ \\ ${ }^{1}$ Institute for Genomics and Evolutionary Medicine, Science \& Education Research Center, \\ Temple University, Philadelphia, Pennsylvania, USA. \\ ${ }^{2}$ Center for Neurogenetics, Brain \& Mind Research Institute, Weill Medical College, Cornell \\ University, New York, New York, USA. \\ ${ }^{3}$ Gale and Ira Drukier Institute for Children's Health, Weill Cornell Medical College, Cornell \\ University, New York, NY, USA.
}

*Alexander G Lucaci \& Michael J Notaras contributed equally and share first authorship.

\section{HIGHLIGHTS}

- We extracted coding sequences for Brain-Derived Neurotrophic Factor (BDNF) from over 160 mammalian genomes that span approximately $\sim 177$ million years of evolution.

- We observe strict purifying selection in the main functional domain (NGF) of the BDNF gene in mammals.

- We observe novel results with 6 sites in our homologous alignment which are under episodic selection in the early regulatory region of BDNF (i.e. the prodomain).

- We observe 23 pairs of coevolving sites within BDNF. Many of which are a part of complex spatial relationships and are distributed across the entire BDNF gene.

- These data define exactly how "BDNF is highly conserved" by defining exactly where and how the mammalian BDNF has evolved, confirming the widespread belief that the BDNF prodomain is more prone to change than the mature BDNF protein.

\section{KEYWORDS}

molecular evolution, brain-derived neurotrophic factor, mammalian gene evolution, gene structure, BDNF, Val66Met, neuropsychiatry 


\begin{abstract}
The mammalian gene Brain-Derived Neurotrophic Factor (BDNF) is an essential mediator of brain assembly, development, and maturation which has been implicated in a variety of brain disorders such as neurodevelopmental disorders (e.g. autism spectrum disorder), neuropsychiatric disorders (e.g. depression, PTSD, schizophrenia), and neurodegenerative disorders (e.g. Parkinson's). Loss of BDNF during early development is embryonic lethal, and depletion of BDNF during adolescence or adulthood can result in disease-related neuropathology across a broad range of model organisms. In order to better understand the role of BDNF in disease, we seek to provide an evolutionary context to BDNF's role within the brain by elucidating the molecular and genetic comparative history of BDNF across species. We conduct sequence alignment and phylogenetic reconstruction of the BDNF gene across a diverse selection of over 160 mammalian species spanning $\sim 177$ million years of evolution. Selective evolutionary change was examined via several independent computational models of codon evolution including FEL, MEME, and BGM. We report strict purifying selection in the main functional domain of BDNF (NGF domain, essentially comprising the mature BDNF protein). Specifically, we discover 6 sites in our homologous alignment which are under episodic selection in the early regulatory region of BDNF (i.e. the prodomain) and 23 pairs of coevolving sites that are a part of complex spatial relationships that are distributed across the entire BDNF gene. Thus, we propose that our discovery of both local and distal sites of co-evolution within the pro- and mature-domains of BDNF that likely reflect the evolutionary fine-tuning of BDNF's unique and complex regulatory capacities whilst also retaining it's core yet diverse ontogenic functionality within the central nervous system. This discovery consequently supports the idea that the BDNF prodomain is more prone to change than the mature domain, however the fact that this region has also been subject to negative purifying selection also highlights genetic sensitivity and thus partially explains the prodomain's disease relevance (e.g. Val66Met and other variants) to numerous neuropsychiatric disorders.
\end{abstract}




\section{INTRODUCTION}

Brain-Derived Neurotrophic Factor (BDNF) is an ubiquitously studied molecule in modern neuroscience [1]. BDNF is a neurotrophin that binds with high affinity to its cognate tyrosine kinase receptor, TrkB [2], to elicit rapid induction of synaptic plasticity [3-5] and neuronal spine remodeling [6, 7]. Additionally, BDNF has been implicated in a variety of brain disorders [1], including depression [8-10], PTSD [11-14], schizophrenia [9, 15-17], Parkinson's disease [18, 19], and autism spectrum disorders [20-22] amongst many more. BDNF has correspondingly been the primary target, or an ancillary factor, of many novel therapeutics including small molecule mimetics [23, 24] and existing drugs (e.g. antidepressants [25, 26]). Yet, nascent research has provided the humbling reminder that much remains to be discovered about BDNF. In recent years, new BDNF ligands have been discovered [27], new receptor interactions unveiled [27, 28], and mechanisms of behavioral function unlocked [7]. This is a timely reminder that while BDNF has remained a seminal molecule of interest across the broader neuroscience literature, much remains to be discovered about its origins, evolution, function, and disease relevance.

\section{A Primer of the Molecular Biology of BDNF and its Functional Topology}

BDNF is encoded by the BDNF gene [29], whose expression is regulated in humans by an antisense-gene (BDNF-AS) that can form RNA-duplexes to attenuate translation [30]. Thus, the natural antisense for BDNF is capable of directly downregulating endogenous expression on demand [31]. The BDNF gene in humans comprises 11 exons [30] and can produce at least 17 detectable transcript isoforms [29]. Different transcripts are induced in response to activity and/or cellular states, allowing the BDNF gene to adjust to environmental stimuli and potential selection pressures. However, all transcripts ultimately yield a singular preproBDNF protein that (prior to intracellular processing, cleavage, and transport) can be partitioned into three domains [11, 29]: a signal peptide, a prodomain, and the mature domain. The signal domain is only 18 amino acid residues long, possessing ambiguously defined functionality, and the majority of BDNFs functional outputs reflect sequence specificity to the prodomain and mature domain. The BDNF prodomain encodes binding sites for intracellular transport of both BDNF mRNA [32] and BDNF protein [33], and contains numerous post-translational modification sites [29]. The BDNF prodomain is also the resident location of a widely studied Single Nucleotide Polymorphism (SNP) in neuroscience (Val66Met, or rs6265) [1], and the Furin consensus sequence (Arg 125) for cleavage to its mature form (including by plasmin [34]). The prodomain is composed of 110 amino acids within the $\mathrm{N}$-terminus, and must be processed via proteases to generate mature BDNF [5]. The mature domain of BDNF is composed of, almost exclusively, the Nerve growth factor (NGF) domain and is responsible for the canonical trophic actions associated with BDNF, e.g., long-term potentiation, rapid acting antidepressant effects. Following intracellular handling, processing, and transport, the preproBDNF isoform is cleaved to yield the mature BDNF peptide (which only contains the mature NGF domain). For many years the prodomain was thought to be cleaved following transport and thus destined for degradation. However, recent work has shown that the cleaved prodomain can be secreted and bind as a ligand to novel receptors (e.g., SorCS2) [27]. Thus, the BDNF prodomain can accordingly influence brain circuits as well as behavior [7]. For a comprehensive, detailed, analysis of the various intricacies of the BDNF gene, protein, and its regulation, more information is provided in [29]. 


\section{The Conservation of BDNF \& Neurotrophins}

One of the interesting curiosities surrounding BDNF is its relationship to other neurotrophic (NT) growth factors, comprising NGF, NT-3, NT-4. Thus, neurotrophins retain some intercalated functionality. Each share some commonalities in structure (pre-, pro-, and mature-domains) [29], post-translational modification potential (e.g. glycosylation [35]), as well as catalytic processing, trafficking, and composition [36]. Specifically, neurotrophins share approximately $50 \%$ sequence homology [29], and a comparison of domains and motifs reveals that each comprises a prototypic NGF-domain as the principal component of the mature pro-growth peptide for each factor (see PFAM database [37]). While each neurotrophin elicits functionality via binding to cognate receptors, neurotrophins also exhibit cross-affinity amongst neurotrophin receptors [38] presumably due to their high rates of structural homology. Not surprisingly then, there is some redundancy in the pro-trophic effects of neurotrophins, yet each still maintains nuanced functionality which remains specific to each factor during central nervous system development [39]. Differences in the evolution and temporal dynamics of regulatory sequences, which target gene-products to specific destinations within cell-compartments (e.g. dendrites) [40] or to processing routes (e.g. the activity-dependent release pathway) which alter secretory dynamics and/or bioavailability [41], likely contribute to both similarities and differences between neurotrophins. However, almost nothing is known of how the BDNF prodomain has evolutionarily adapted to specifically regulate BDNF dynamics. While evolution has almost certainly shaped the sequences, structure, and function of BDNF, the modeling of such remains relatively unexplored but could provide important insight into the phylogenetic evolutionary history of BDNF, it's selection pressure sensitivity across lineages, and quantitative metrics of evolutionary change across species.

\section{Purpose of this Study}

Here, we use computational methods to explore the comparative evolutionary genomics of the neurotrophic factor BDNF. By reconstructing phylogenetic trees of BDNF in mammals (Mammalia), we utilize sequence alignments of over 160 species to determine unique genomic attributes of BDNF. In specific we investigate which sites in BDNF are subject to pervasive (i.e., consistently across the entire phylogeny) diversifying selection (FEL) or pervasive/episodic (i.e., only on a single lineage or subset of lineages, diversifying selection (MEME). Likewise, utilizing multiple models for the inference of selective pressure and the evaluation of evolutionary change, we identify novel sites within the BDNF prodomain and mature peptide coding regions that are susceptible to synonymous and nonsynonymous changes. Additionally we investigate which sites in BDNF may be coevolving (BGM). Taken together, these computational evolutionary analyses provide an important context as to the origins and sensitivity of genetic changes within the BDNF gene, which may be important for providing insight into genetic risk factors linked to disease in humans. 


\section{RESULTS}

We find that unique evolutionary pressures have shaped the BDNF gene across time. Mostly, these forces have operated through strict purifying selection. Of note, BDNF elicits tight regulation and specific functionality that can be separated from other neurotrophins, yet these growth factors remain closely related in their structure and sequence, especially in the conserved NGF domain.

\section{Evolutionary History of Mammalian BDNF}

Prior to conducting our primary evolutionary analysis, we ported our mammalian species into a platform (timetree.org, see $[42,43]$ ) to examine the epoch events that may have influenced the analysis described here. This was an important pre-analysis step to frame the age of our genomes, and the broad-strokes evolutionary pressures that these species have been exposed to (which, in theory, could contribute to subsequent purifying selection and coevolution analyses). As expected, this revealed BDNF as an ancient gene that has been preserved throughout the mammalian lineage and has both survived and been shaped under all major evolutionary events of the past $\sim 177$ million years (data not shown). For species within our data-set we identified several examples of species-level evolutionary epochs that cross-referenced with major earth events (e.g. bottleneck events) that have historically been believed to drive evolutionary adaptation. This included major geologic periods that are cross-referenced against earth impacts, oxygenation changes across time, atmospheric carbon dioxide concentrations, and solar luminosity. This indicates that even under extreme evolutionary pressures, the BDNF gene has exhibited (relatively speaking) very specific adaptation events (see results below) over millions of years in mammals. This tracks with the idea that "old genes" tend to be highly conserved, evolve more slowly, and therefore are more likely to exhibit both specific and selective changes as opposed to more dramatic permutations (e.g. gene duplications etc.).

\section{Predominant Purifying Selection in BDNF}

A common approach to gain an increased understanding of the evolutionary forces that have shaped proteins is to measure the omega ratio $\omega$ consisting of the non-synonymous ( $\beta$ or $\mathrm{dN}$ ) and synonymous ( $\alpha$ or $\mathrm{dS}$ ) substitution rates with $\omega=\beta / \alpha$ for each site in a particular gene of interest [47]. We define two major substitional changes for the amino acid being coded for at each site: synonymous changes, which keep the same amino acid coded for at a particular site and nonsynonymous changes, which change the amino acid coded for at that particular site. Nonsynonymous changes can have strong influences on the structural, functional, and fitness measures of an organism. This is in contrast to synonymous changes which leave the amino acid at a particular site unchanged, but can confer weak fitness effects through the emergent properties of codon usage bias, mRNA structural stability, translation and tRNA availability. However, synonymous changes are typically understood to represent neutral selection acting on coding sequences, and provides a baseline rate against which non-synonymous evolutionary rates can be compared. The omega ratio $\omega$ of relative rates of non-synonymous and synonymous substitutions is a common measure in evolutionary biology of the selective pressure acting on protein coding sequences. These estimates provide increased information availability as to the 
type of selection (positive, with omega $>1$ or negative, with omega $<1$, or neutral with omega $=$ 1 ) that has acted upon any given set of protein-coding sequences.

As FEL analysis is a sensitive measure of negative (purifying) selection, for our FEL analysis, we observe a predominant amount of purifying selection (over $66 \%$ of sites, 174 sites out of 261; Table S1) in our recombination free alignment for BDNF. The dN/dS estimates for the entire alignment were plotted including 95\% lower- and upper-bound estimates (see Figure 1 or Table S1). Overwhelmingly, the mature NGF-domain of the BDNF exhibited evidence of greater pervasive negative purifying selection relative to the prodomain region of BDNF. Thus over the evolutionary history in mammalia, negative selection has predominantly occurred in the regions of BDNF that encode the functional mature protein that binds TrkB to elicit neurotrophic effects. The mature domain of BDNF has exhibited remarkable conservation across innumerous epochs defined by rapid evolutionary adaptation (see Figure 1) in other genes and species. 


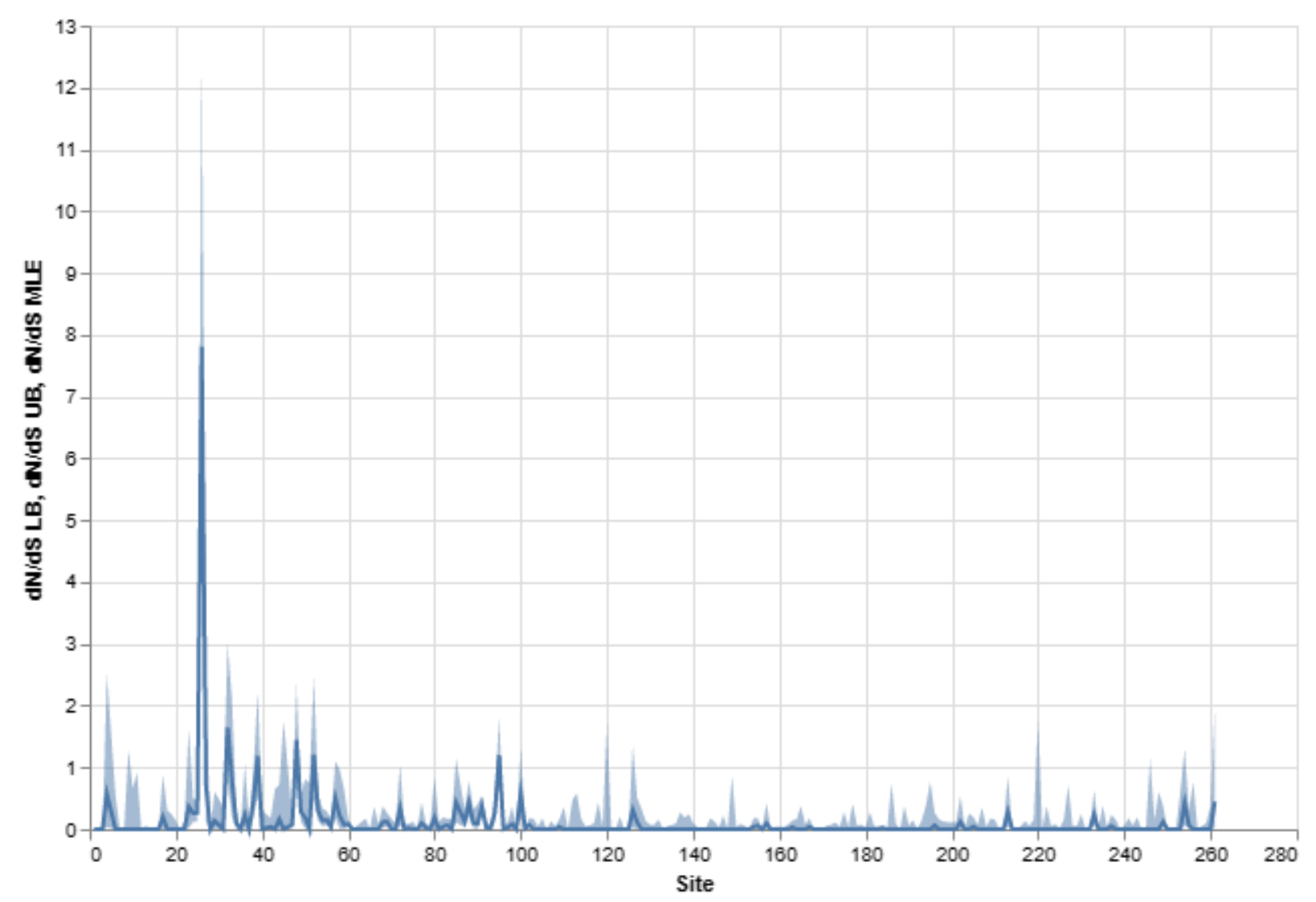

Figure 1. The FEL analysis of the BDNF gene found 174 of $261(66.7 \%)$ sites to be statistically significant (LRT $p$-value $<=0.1$ ) for pervasive negative (purifying) selection. We plot the estimated values of omega (dN/dS) for each site in the alignment. Additionally, we plot $95 \%$ confidence intervals $(\mathrm{Cl})$ for each site. These results are also available in Table S1. We observe a high degree of strict purifying selection in the Human NGF region. The region for Human NGF corresponds to alignment sites 144-254 (NP 001700.2,

and https://github.com/aglucaci/AnalysisOfOrthologousCollections/blob/main/tables/BDNF/B DNF AlignmentMap.csv). This alignment of BDNF across all selected species (Mammalia, see Table 1) reveals a site-specific positive/adaptive diversifying selection and negative purifying selection. The thick line represents the point estimate (i.e. the evolutionary pressure) and the shadings reflect $95 \%$ confidence intervals which relate to the upper and lower bound of the point estimates. As shown, the prodomain sites exhibit more pervasive/episodic and positive/diversifying evolutionary selection, consistent with the fact that more disease associated SNPs occur in this topological region of the BDNF gene in humans (i.e. early prodomain mapping not further shown due to nuanced variation across mammalian species). 


\section{Specific Sites that are Evolving Non-Neutrally}

To examine specific sites for episodic adaptive evolutionary selection, we utilized an algorithm known as MEME which is fundamentally similar to our FEL analysis (described above) except that it applies a more sensitive method for the detection of both pervasive (persistent) and episodic selection (transient selection occurring only on one or a subset of branches in the phylogenetic tree) as compared to only pervasive selection which occurs across all branches of the phylogenetic tree. Essentially, only a subset of the lineages (i.e. species) are affected allowing for a more granular/sensitive method of detecting selection (whereas FEL is better geared towards broad changes). This analysis revealed that for all sites, only $2.3 \%$ (6 of 261 ; see Table 2) exhibit evidence for episodic diversifying selection (i.e. positive selection) in at least one branch within the phylogeny. Spatially, these mutations occur outside of the NGF functional region of BDNF. Further, this result is essentially relevant as the MEME analysis is a sensitive measure of episodic selection. The sites we observe as statistically significant are as follows: $26,27,30,38$, 249,254 . For comparison, these specific sites were re-aligned to the respective human sites with indel (insertion/deletion) events accounting for any respective discrepancy in specific site numbers. When mapping these sites to the human BDNF coordinate system, they correspond to: $26,27,29,36,238,240$, respectively. 


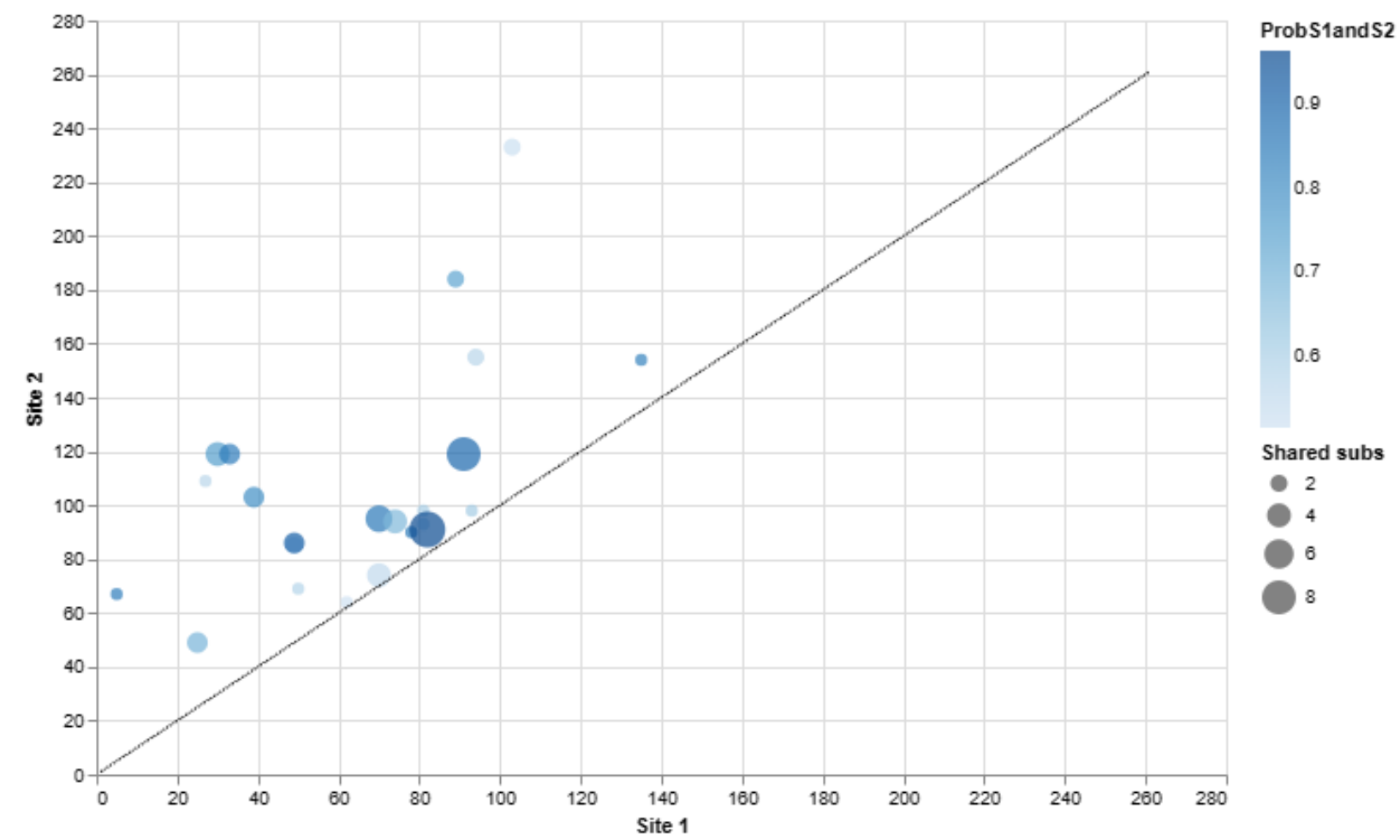

Figure 2. The BGM analysis of BDNF found 23 pairs of coevolving sites out of 261 total sites to be statistically significant (with a posterior probability threshold $\mathbf{0 . 5}$ ). Here, we plot only the statistically significant co-evolving pairs. The number of shared substitutions between pairs of co-evolving sites is visualized by the size of the circle, with larger circles indicating more shared substitutions. Poster probability of the interaction (coevolving pair) corresponds to the color blue, with dark blue indicating higher values. Individual BDNF sites are mapped on both the $X$ and $Y$ axis so that readers can view which sites are coevolving with another. Once more, note that the coevolution tends to be focally constrained to the broader BDNF prodomain region at a topological level, which is once more consistent with the idea that the NGF domain (site $>144$; see Figure 3 ) is highly conserved and probably deleteriously impacted by variation. However, we did discover four sites of coevolution in the NGF domain (basically, the mature BDNF protein) that are evolving with early prodomain sites. This highlights that both proximal and distal sites in BDNF can, and indeed are, evolving together over time.

\section{Evidence of Coevolutionary Forces}

To examine the coevolution of sites, i.e. if one particular amino acid was evolving intandem with another, we subjected our protein-coding gene sequences to the BGM algorithm which leverages Bayesian graphical models [51]. The BGM algorithm infers substitution history through the use of maximum-likelihood analyses for ancestral sequences and maps these to the phylogenetic tree, which allows for the detection of correlated patterns of substitution [51]. For our BGM analysis, we find evidence for 23 pairs of coevolving sites. This suggests interaction 
dynamics in tertiary space of the 3D, folded, protein level (see relevant sites in Figure 2) BDNF protein structure. Or, otherwise, is evidence for coevolving sites due to other fitness consequences related to compensation for maladaptive changes in one part of the protein sequence that may have occurred. When we review these sites, we notice that several pairs (see Figure 2) occur within alignment sites which correspond to the Human BDNF coordinate system (Table 2). These include sites $(89,184),(94,155),(103,233),(135,154)$. Of note, several other sites also display interesting geometric features including triangular relations: $[(81,93),(93,98)$, $(81,98)]$, an acyclic graph network of site connections $[(70,74),(74,94),(94,155)]$ and $[(25,49)$, $(49,85),(49,86)]$, and more complex double linked co-evolutionary sites: $[(39,103),(103,233)]$, and triple linked co-evolutionary sites: $[(30,119),(33,119),(91,119)]$. Additionally, threedimensional reconstruction - here focusing on a specific heterodimer configuration of BDNF and NT-4 as an example of a spatial protein-protein interaction - highlights that coevolving sites as well as positively evolving sites are likely to have been "fine tuned" over time to help support BDNF's cognate functionality (see Figure 3). Mapping our FEL purifying sites in a structural configuration was not shown due to the overwhelming nature of negative selection acting on BDNF within mammals. 

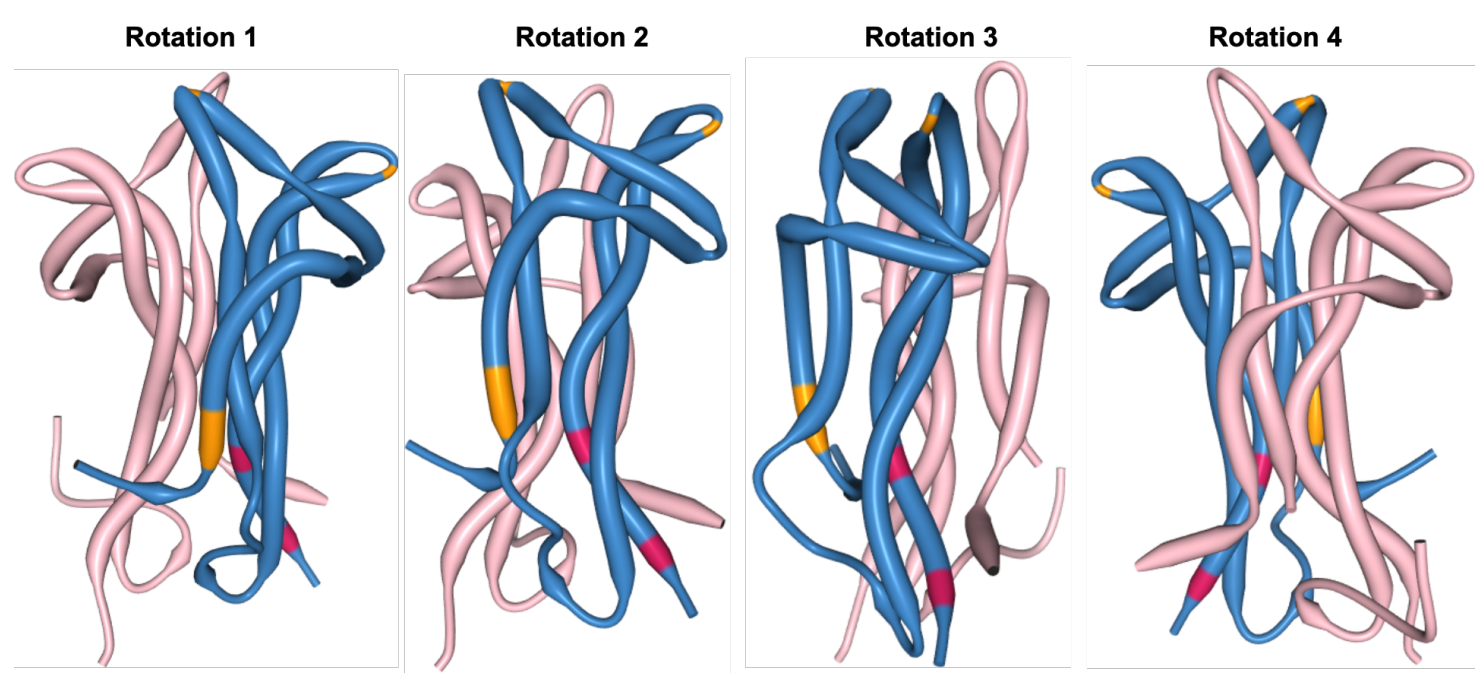

Figure 3. BDNF NT-4 Heterodimer Structural Analysis to Highlight Coevolving and Adaptive Sites at the 3D Protein Level. Demonstrating the structural configuration of the BDNF (blue) and NT-4 (pink) heterodimer (see https://www.rcsb.org/structure/1B8M), with rotations (arbitrary degrees) shown to accentuate view of coevolving sites (orange, see also Figure 2 and Table 3) and positively evolving sites (red; see Table 2). The PDB structure is limited largely to the NGF domain which limits our ability to highlight sites of interest (SOI), therefore we have limited our annotation only to the modeled sites in the structure. The relative positioning of coevolving and positively evolving sites in this heterodimer visualization (proximity to looping and other macro tertiary structures of protein). An interactive figure that is rotatable in 3D space, where occupations occur in three-dimensions (i.e. teasing out relative proximity in 2D linear space), is available here https://observablehq.com/@aglucaci/bdnf-structure.

\section{DISCUSSION}

In this study, we explore the evolutionary history of the BDNF gene in Mammalia. The BDNF gene is implicated in a number of human diseases including a variety of brain disorders such as neurodevelopmental disorders (e.g. autism spectrum disorder), neuropsychiatric disorders (e.g. depression, PTSD, schizophrenia), and some neurodegenerative disorders [1]. By using orthologous BDNF sequences within the Mammalia taxonomic group, our results indicate that within species, unique evolutionary pressures and site-specific changes within the BDNF gene have evolved across time. We performed a number of comparative evolutionary analyses to tease out signals from our orthologous gene collection in BDNF. Of note, the BDNF gene elicits tight regulation and specific functionality that can be separated from other neurotrophins, yet these growth factors remain closely related in their structure and sequence and conservation of the NGF functional domain. In the NGF domain, we observe a high degree of conservation (via purifying selection) across species, owing to the functional importance of this region in proteinprotein interactions. This work additionally provides broad comparative insights into the 
evolutionary history of the BDNF gene family. Our MEME method identified novel substitutions (see Table 2) in regions of BDNF that may provide significant areas of interest for designing molecular therapeutic approaches, and their potential broader significance are outlined in further detail below.

\section{Predominant purifying selection across BDNF in Mammalia}

Over time, evolution drives the divergence of genetic sequences. What can we learn from the direct comparison of the sequences of the BDNF gene in Mammalia? By comparing the BDNF products of orthologous genes in different species we observe the accumulation of mutations at different sites with varying degrees of insight into both BDNF functionality (see [29] for site annotation) and potential disease [1]. These are summarized in-full within Table S1 and Table 2. Coding sequences with highly constrained structures are expected to fix non-synonymous mutations at a slower rate due to the maladaptive nature of changes such as what we observe with the FEL negatively selected sites across BDNF. Additionally, we observe a high degree of negative (purifying) selection across the main functional domain (NGF) of BDNF. While structures for the NGF domain in most species under analysis do not exist, based on our findings we expect a highly conserved tertiary structure. Based on the high degree of purifying selection observed across BDNF, we hypothesize that BDNF plays a critical role in the underlying network of genes governing homeostasis and normal organismal development. This may have happened because BDNF is particularly useful specifically for the phylogenetic branch in question (i.e. mammals). This interpretation also tracks with the observation that BDNF is essential for normative development and is basically lethal in non-conditional full knock-out mammalian models.

\section{Non-Neutral Positive Diversifying Evolution Sites in the BDNF Gene}

It has been described that BDNF particularly plays a role as a foundational gene for brain development [11]. Despite a significant level of purifying selection shaping the evolutionary history of BDNF (Figure 1), we observe several novel statistically significant sites under positive episodic diversifying selection across the BDNF gene (see Table 2). Traditionally, evolution of this variety consists of amino acid diversifying events that may promote phylogenetic adaptation and/or functionality. These results are entirely novel - they have not been previously reported (to the best of our knowledge) and MEME is an established and sensitive method for the analysis of episodic diversifying sites. Thus, the very specific and limited sites within BDNF to exhibit such patterns is a highly promising result from which to further disentangle BDNFs complex functionality and disease linkage. Presumably, we would encourage biologists to consider these sites as those that may contain important adaptive functions within the BDNF gene. However, where our results fall within the context of a core protein-protein interaction network of required genes for neural cellular diversity and development is yet to be determined. We do note that at least one identified site (238) overlaps with potential post-translational modifications to the human BDNF peptide (specifically, a disulfide bridge; see UniProt and [29]). This supports the idea that non-neutral positive diversifying sites within BDNF are not spurious and likely reflect specialized, regulatory, or functional capacities that may have yet to be annotated in-full. Given that this manuscript is devoted to analysis of BDNF's evolution in mammals, we highlight the potential importance of 
these sites but emphasize that their importance remains a hypothesis that should be tested in well-defined experiments under controlled laboratory conditions.

\section{Discovery of Proximal \& Distal Coevolving Site-Pairs in the BDNF Gene}

Another novel, and potentially important, series of findings in this manuscript was the presence of numerous sites that exhibit coevolution. In fact, we observe a significant number of coevolving sites within the BDNF gene (see Figure 2, Table 3), and these too reflect an entirely novel aspect of BDNF biology that has not previously been reported. Evidence of coevolving sites are not limited to a particular domain (e.g. prodomain vs mature) nor specific motifs. Instead, coevolving pairs seem to be distributed across the entire BDNF gene with, perhaps unsurprisingly, an increased density of interactions early in the pre-pro domain region. However, we also note that there are coevolving sites in the mature NGF domain which are "linked" to early domain sites. Importantly, these relationships may confer strong epistatic interactions shaping the continued evolution of this critically important gene. The new evidence for coevolution may point to the importance of these sites in shaping the early regulatory or main functional (NGF) domain of BDNF. These residues may form important interactions for the functional integrity of BDNF and, importantly, the highly specific pairs which span the BDNF prodomain and its mature region point to a new mechanism by which the BDNF prodomain may have co-regulated the mature domain (or vice versa). Alternatively, these coevolving pairs may be part of a network of residues occupying a shifted fitness landscape in order to accommodate new or species-specific functional requirements.

\section{Potential Structural Implications of Evolving Sites}

In considering our observation of both diversifying selection and coevolving sites in the BDNF gene, we considered the potential implications this may have at a protein structural level in three-dimensional space (see Figure 3). While protein structural impacts from evolution remain poorly understood and cannot be completely experimentally disentangled in a confirmatory sense, the implications fall upon our understanding of basic BDNF neurobiology. Here we note that our BGM and FEL analyses implicate the prodomain - the primary topological region of BDNF known for polymorphic variability (e.g. Val66Met, Gln75His) that is often linked to disease [1, 11, 29], and our 3D modeling suggests that two of our co-evolving sites appear to be associated with looping structures that could have important yet to be discovered functionality. In this regard, we predict that the evolutionary changes described here are likely to reflect some form of specialization and/or divergence in function and/or interaction partners at different points of BDNF's evolutionary history in mammals. Thus, further work may unveil yet more novel sites that could provide further insight into the origins of BDNF's diverse functionality and its role in disease.

\section{Limitations of our Computational Evolutionary Analysis}

This analysis focused on BDNF sequences contained in the taxonomic group Mammalia in lieu of examining a more inclusive dataset for BDNF containing sequences from all of Gnathostomata (jawed vertebrates) or extension into invertebrate clades which may contain BDNF or BDNF-like analogue genes. Our results are applicable to mammals, which are our intentional taxonomic group of study, but we nonetheless emphasize that our results do not 
capture the entirety of BDNF's evolutionary history (e.g. there could be more to learn about BDNF from birds, lizards, fish, and higher order taxonomic groups which we do not evaluate here). In addition we do not explore the patterns or mutational processes occurring outside of codingsequence evolution which include complex structure and dynamics of non-coding regions in the BDNF gene or across. Therefore, evolutionary temporality is important in the context and interpretation of our results because Mammalia represents only a portion of the long evolutionary history of BDNF. Although we failed to find evidence for recombination in our dataset, species where we may find evidence for recombination may have been precluded from our analysis due to our decision to focus on Mammalian BDNF gene evolution. Further, a limitation of the current analysis is owed to the presence of indel events, especially in the early region of the alignment but which also occur in other spatially distributed regions of the BDNF gene. These indel events are not currently modeled in existing codon substitution models but may represent an additional pathway of evolutionary change. Nonetheless, the prominence of indels in our observations indicate that several regions of BDNF may evolve significantly through indel events across species. Lastly, although there is a risk that the "gappy" nature of the early region of our multiple sequence alignment may be a computational artifact of the alignment procedure, based on all other outputs we believe that our results are reasonably interpreted and have subsequently tolerated these potential effects.

\section{Future Directions: Understanding the Remainder of the Neurotrophin Family}

We hypothesize that the similarities between neurotrophins reflects conserved evolutionary selection for motifs and domains for which support common functionality in neurotrophic factors between sites and lineages. While we note significant isotropy in mature peptide sequences for these factors, anisotropic pressures likely influenced the prodomain sequences of neurotrophins leading to alterations in processing, trafficking, regulation, and secretion. As such, we also predict differences in the evolutionary fate of other neurotrophins which also exhibit compartmentalized functionality due to similar alterations within their prodomains (i.e. similar results may be reasonably anticipated not just in BDNF, but also NGF, NT-3, and NT-4).

\section{CONCLUSION}

To sum up, our research modeled the natural evolutionary history of changes in the BDNF gene across >160 mammalian genomes. Conservatively, this analysis spans approximately $\sim 177$ million years of evolution - and going deeper could yet reveal more information on the ontogenesis of BDNF and its topological structure (and, consequently, function). Notably, we observed strict purifying selection in the main functional domain of the BDNF gene in mammals and discovered 6 specific sites in our homologous alignment that are under episodic selection in the early regulatory region of BDNF (i.e. the prodomain) and in the terminal region of BDNF. We also make the case for spatial coevolution within this gene, with 23 pair-sites that have evolved together. In sum, these data go above and beyond the common trope that "BDNF is highly conserved" by defining exactly where and how the mammalian BDNF has evolved. Thus, we confirm the widespread belief that the BDNF prodomain is more prone to change than the mature BDNF protein, having important implications for how we think about and consider genetic variation in BDNF and its linkage to disease. 


\section{METHODS}

\section{Data Retrieval}

For this study, we queried the NCBI Ortholog database via https://www.ncbi.nlm.nih.gov/kis/ortholog/627/?scope=7776. For the purpose of this study, as we are interested in mammalian BDNF evolution, we limited our search to only include species from this taxonomic group (mammals, Mammalia). This returned 162 full gene transcripts and protein sequences. We downloaded all available files: RefSeq protein sequences, RefSeq transcript sequences, Tabular data (CSV, metadata). In Table 1, we provide a table of the species included in this analysis but we also make this accessible via GitHub. Furthermore, we also make these species NCBI accessions (see also Table 1) available for download on GitHub:

- AnalysisOfOrthologousCollections/BDNF orthologs.csv at main . aglucaci/AnalysisOfOrthologousCollections · GitHub

\section{Data Cleaning}

We used the protein sequence and full gene transcripts to derive coding sequences (CDS) (via a custom script, scripts/codons.py). However, this process was met with errors in 20 "PREDICTED" protein sequences which had invalid characters such as sequences which have incorrect ' $X$ ', or unresolved amino acids and these sequences were subsequently exempt from analysis. This process removes low-quality protein sequences from analysis which may inflate rates of nonsynonymous change.

Analysis of Orthologous Collections (AOC): Alignment, Recombination Detection, Tree inference \& Selection Algorithms

The Analysis of Orthologous Collections (AOC) application is designed for comprehensive protein-coding molecular sequence analysis (https://github.com/aglucaci/AnalysisOfOrthologousCollections). It accomplishes this through a series of comparative evolutionary methods. AOC allows for the inclusion of recombination detection, a powerful force in shaping gene evolution and interpreting analytic results. As well, it allows for lineage assignment and annotation. This feature (lineage assignment) allows between group comparisons of selective pressures. This application currently accepts two input files: a protein sequence unaligned fasta file, and a transcript sequence unaligned fasta file for the same gene. Typically, this can be retrieved from public databases such as NCBI Orthologs. Although other methods of data compilation are also acceptable. In addition, the application is easily modifiable to accept a single CDS input, if that data is available.

If protein and transcript files are provided, a custom script 'scripts/codons.py' is executed and returns coding sequences where available. Note that this script currently is set to use the standard genetic code, this will need to be modified for alternate codon tables. This script also removes "low-quality" sequences if no match is found, see the above Data cleaning section.

Step 1. Alignment. We used the HyPhy [44] codon-aware multiple sequence alignment procedure available at (https://github.com/veg/hyphy-analyses/tree/master/codon-msa). 
This was performed with a Human BDNF coding sequence NM_001709.5 Homo sapiens brain derived neurotrophic factor (BDNF), transcript variant 4, $m R N A$ as a reference based alignment. Our alignment procedure retained 126 unique in-frame sequences.

Step 2. Recombination detection. Performed manually via RDP v5 [45], see below, the "Recombination detection" section for additional details. A recombination free file is placed in the following folder: results/BDNF/Recombinants. For the purpose of this study, we did not detect recombination in our dataset.

Step 3. Tree inference and selection analyses. For the recombination free fasta file, we perform maximum likelihood phylogenetic inference via IQ-TREE [46]. Next, the recombination free alignment and unrooted phylogenetic tree is evaluated through a standard suite of molecular evolutionary methods. This set of selection analyses include the following but for the sake of brevity some of these results were not shown (essentially, most were not statistically significant or not meaningful as relevant to the evolutionary results presented here).

- FEL: locates codon sites with evidence of pervasive positive diversifying or negative selection [47].

- BUSTEDS: tests for gene-wide episodic selection [48].

- MEME: locates codon sites with evidence of episodic positive diversifying selection, [49].

- aBSREL: tests if positive selection has occurred on a proportion of branches, [50].

- SLAC: performs substitution mapping, [47].

- BGM: identifies groups of sites that are apparently co-evolving, [51].

- RELAX: compare gene-wide selection pressure between the query clade and background sequences, [52].

- CFEL: comparison site-by-site selection pressure between query and background sequences, [53].

- FMM: examines model fit by permitting multiple instantaneous substitutions, [54].

Step 4A. Lineage assignment and tree annotation. For the unrooted phylogenetic tree, we perform lineage discovery, via $\mathrm{NCBI}$ and the python package ete3 toolkit. Assigning lineages to a $\mathrm{K}$ (by default, $\mathrm{K}=20$ ) number of taxonomic groups. Here, the aim is to have a broad representation of taxonomic groups, rather than the species being heavily clustered into a single group. As a reasonable approximation, we aim for $<40 \%$ of species to be assigned to any one particular taxonomic group.

Step 4B. We perform tree labeling via the hyphy-analyses/Label-Trees (REF, link) method. Resulting in one annotated tree per lineage designation. For the purpose of this study, we will only consider the following five lineages for additional analyses (Artiodactyla, Carnivora, Chiroptera, Glires, Primates) as they are the most populated lineages. 
Step 5. Selection analyses on lineages. Here, the recombination free fasta file and the set of annotated phylogenetic trees (where labeling was performed in Step 4) is provided for analysis with the RELAX and Contrast-FEL methods.

Recombination detection

Manually tested via RDPv5.5 with modified settings as follows:

- We also included the following algorithms/analyses: RDP [55], GENECONV [56], Chimaera [57], MaxChi [58], BootScan [59] (Primary and Secondary Scan), SiScan [60] (Primary and Secondary Scan), 3Seq [61].

- Recombination events are 'accepted' in cases where 3 or more methods are in agreement.

- We slightly modified default parameters, such that

○ Require topological evidence.

- Polish breakpoints.

- Check alignment consistency.

- Sequences are linear.

- List events detected by $>2$ methods.

- We manually recheck all of the events via "Recheck all identified events with all methods".

- We manually accept events detected by $>2$ methods.

- The resulting alignment was saved as a distributed alignment (with recombinant regions separated).

Recombination was not detected within our Human reference based alignment. Therefore we used the single recombination free alignment for analyses.

\section{Data \& Software Availability Statement}

The AOC application is freely available via a dedicated GitHub repository at: https://github.com/aglucaci/AnalysisOfOrthologousCollections

Raw data for this study is available on GitHub: https://github.com/aglucaci/AnalysisOfOrthologousCollections/tree/main/data/BDNF

Full results for this study include all HyPhy selection analyses JSON-formatted result files are available on GitHub:

https://github.com/aglucaci/AnalysisOfOrthologousCollections/tree/main/results/BDNF

\section{Conflicts of Interest Statement}

The authors are without conflict.

\section{Contributions \& Acknowledgements}

M.N. and A.L. contributed equally. M.N. was supported by a NHMRC CJ Martin Fellowship for stem cell training at Weill Cornell Medical College. 


\section{REFERENCES}

1. Notaras, M., R. Hill, and M. van den Buuse, The BDNF gene Val66Met polymorphism as a modifier of psychiatric disorder susceptibility: progress and controversy. Mol Psychiatry, 2015. 20(8): p. 916-930.

2. Nagappan, G. and B. Lu, Activity-dependent modulation of the BDNF receptor TrkB: mechanisms and implications. Trends in Neurosci, 2005. 28(9): p. 464-471.

3. Black, I.B., Trophic regulation of synaptic plasticity. J Neurobiol, 1999. 41(1): p. 108-118.

4. Yoshii, A. and M. Constantine-Paton, Postsynaptic BDNF-TrkB signaling in synapse maturation, plasticity, and disease. Dev Neurobiol, 2010. 70(5): p. 304-322.

5. Sakuragi, S., K. Tominaga-Yoshino, and A. Ogura, Involvement of TrkB-and p75 NTRsignaling pathways in two contrasting forms of long-lasting synaptic plasticity. Sci Reps, 2013. 3(1): p. 1-7.

6. Horch, H.W., et al., Destabilization of cortical dendrites and spines by BDNF. Neuron, 1999. 23(2): p. 353-364.

7. Giza, J.I., et al., The BDNF Val66Met prodomain disassembles dendritic spines altering fear extinction circuitry and behavior. Neuron, 2018. 99(1): p. 163-178. E6.

8. Martinowich, K., H. Manji, and B. Lu, New insights into BDNF function in depression and anxiety. Nature Neurosci, 2007. 10(9): p. 1089-1093.

9. Angelucci, F., S. Brene, and A. Mathe, BDNF in schizophrenia, depression and corresponding animal models. Mol Psychiatry, 2005. 10(4): p. 345-352.

10. Kim, Y.-K., et al., Low plasma BDNF is associated with suicidal behavior in major depression. Prog Neuropsychopharmacol Biol Psychiatry, 2007. 31(1): p. 78-85.

11. Notaras, M. and M. van den Buuse, Neurobiology of BDNF in fear memory, sensitivity to stress, and stress-related disorders. Mol Psychiatry, 2020. 25(10): p. 2251-2274.

12. Pivac, N., et al., The association between brain-derived neurotrophic factor Val66Met variants and psychotic symptoms in posttraumatic stress disorder. World J Biol Psychiatry, 2012. 13(4): p. 306-311.

13. Pitts, B.L., et al., BDNF Val66Met polymorphism and posttraumatic stress symptoms in US military veterans: Protective effect of physical exercise. Psychoneuroendocrinol, 2019. 100: p. 198-202.

14. Zhang, L., et al., PTSD risk is associated with BDNF Val66Met and BDNF overexpression. Mol Psychiatry, 2014. 19(1): p. 8-10.

15. Notaras, M., R. Hill, and M. Van den Buuse, A role for the BDNF gene Val66Met polymorphism in schizophrenia? A comprehensive review. Neurosci Biobehav Rev, 2015. 51: p. 15-30.

16. Gratacòs, M., et al., Brain-derived neurotrophic factor Val66Met and psychiatric disorders: meta-analysis of case-control studies confirm association to substancerelated disorders, eating disorders, and schizophrenia. Biol Psychiatry, 2007. 61(7): p. 911-922.

17. Zakharyan, R., et al., Functional variants of the genes involved in neurodevelopment and susceptibility to schizophrenia in an Armenian population. Human Immunol, 2011. 72(9): p. 746-748.

18. Howells, D., et al., Reduced BDNF mRNA expression in the Parkinson's disease substantia nigra. Exp Neurol, 2000. 166(1): p. 127-135.

19. Palasz, E., et al., BDNF as a promising therapeutic agent in Parkinson's disease. Int J Mol Sci, 2020. 21(3): p. 1170.

20. Correia, C., et al., Increased BDNF levels and NTRK2 gene association suggest a disruption of BDNF/TrkB signaling in autism. Genes, Brain, Behav, 2010. 9(7): p. 841848. 
21. Ricci, S., et al., Altered cytokine and BDNF levels in autism spectrum disorder. Neurotox Res, 2013. 24(4): p. 491-501.

22. Tsai, S.-J., Is autism caused by early hyperactivity of brain-derived neurotrophic factor? Med Hypotheses, 2005. 65(1): p. 79-82.

23. Massa, S.M., et al., Small molecule BDNF mimetics activate TrkB signaling and prevent neuronal degeneration in rodents. J Clin Investig, 2010. 120(5): p. 1774-1785.

24. Kingwell, K., BDNF copycats. Nature Rev Drug Discov, 2010. 9(6): p. 433-433

25. Chen, B., et al., Increased hippocampal BDNF immunoreactivity in subjects treated with antidepressant medication. Biol Psychiatry, 2001. 50(4): p. 260-265.

26. Björkholm, C. and L.M. Monteggia, BDNF-a key transducer of antidepressant effects. Neuropharmacol, 2016. 102: p. 72-79.

27. Anastasia, A., et al., Val66Met polymorphism of BDNF alters prodomain structure to induce neuronal growth cone retraction. Nat Comm, 2013. 4(1): p. 1-13.

28. Glerup, S., et al., SorCS2 is required for BDNF-dependent plasticity in the hippocampus. Mol Psychiatry, 2016. 21(12): p. 1740-1751.

29. Notaras, M. and M. van den Buuse, Brain-derived neurotrophic factor (BDNF): novel insights into regulation and genetic variation. The Neuroscientist, 2019. 25(5): p. 434454.

30. Pruunsild, P., et al., Dissecting the human BDNF locus: bidirectional transcription, complex splicing, and multiple promoters. Genomics, 2007. 90(3): p. 397-406.

31. Lipovich, L., et al., Activity-dependent human brain coding/noncoding gene regulatory networks. Genetics, 2012. 192(3): p. 1133-1148.

32. Chiaruttini, C., et al., Dendritic trafficking of BDNF mRNA is mediated by translin and blocked by the G196A (Val66Met) mutation. Proc Nat Acad Sci USA, 2009. 106(38): p. 16481-16486.

33. Chen, Z.-Y., et al., Sortilin controls intracellular sorting of brain-derived neurotrophic factor to the regulated secretory pathway. J Neurosci, 2005. 25(26): p. 6156-6166.

34. Gray, K. and V. Ellis, Activation of pro-BDNF by the pericellular serine protease plasmin. FEBS letters, 2008. 582(6): p. 907-910.

35. del Carmen Cardenas-Aguayo, M., et al., Neurogenic and neurotrophic effects of BDNF peptides in mouse hippocampal primary neuronal cell cultures. PloS One, 2013. 8(1): p. E53596.

36. Maisonpierre, P.C., et al., Human and rat brain-derived neurotrophic factor and neurotrophin-3: gene structures, distributions, and chromosomal localizations. Genomics, 1991. 10(3): p. 558-568.

37. Finn, R.D., et al., The Pfam protein families database: towards a more sustainable future. Nucleic Acids Research, 2016. 44(D1): p. D279-D285.

38. Rodriguez-Tebar, A., G. Dechant, and Y.-A. Barde, Binding of brain-derived neurotrophic factor to the nerve growth factor receptor. Neuron, 1990. 4(4): p. 487-492.

39. Castellani, V. and J. Bolz, Opposing roles for neurotrophin-3 in targeting and collateral formation of distinct sets of developing cortical neurons. Development, 1999. 126(15): p. 3335-3345.

40. Kuczewski, N., et al., Activity-dependent dendritic release of BDNF and biological consequences. Mol Neurobiol, 2009. 39(1): p. 37-49.

41. Chen, Z.-Y., et al., Variant brain-derived neurotrophic factor (BDNF)(Met66) alters the intracellular trafficking and activity-dependent secretion of wild-type BDNF in neurosecretory cells and cortical neurons. J Neurosci, 2004. 24(18): p. 4401-4411.

42. Kumar, S., et al., TimeTree: a resource for timelines, timetrees, and divergence times. Mol Biol Evol, 2017. 34(7): p. 1812-1819. 
43. Hedges, S.B., J. Dudley, and S. Kumar, TimeTree: a public knowledge-base of divergence times among organisms. Bioinformatics, 2006. 22(23): p. 2971-2972.IQTREE reference.

44. Sergei L Kosakovsky Pond, Art FY Poon, Ryan Velazquez, Steven Weaver, N Lance Hepler, Ben Murrell, Stephen D Shank, Brittany Rife Magalis, Dave Bouvier, Anton Nekrutenko, Sadie Wisotsky, Stephanie J Spielman, Simon DW Frost, Spencer V Muse (2020) HyPhy 2.5-A Customizable Platform for Evolutionary Hypothesis Testing Using Phylogenies. 1 Molecular Biology and Evolution 37.1 (2020): 295-299.

45. Martin DP, Murrell B, Golden M, Khoosal A, \& Muhire B (2015) RDP4: Detection and analysis of recombination patterns in virus genomes. Virus Evolution 1: vev003 doi: 10.1093/ve/vev003.

46. B.Q. Minh, H.A. Schmidt, O. Chernomor, D. Schrempf, M.D. Woodhams, A. von Haeseler, R. Lanfear (2020) IQ-TREE 2: New models and efficient methods for phylogenetic inference in the genomic era. Mol. Biol. Evol., 37:1530-1534. https://doi.org/10.1093/molbev/msaa015

47. Sergei L. Kosakovsky Pond and Simon D. W. Frost (2005) Not So Different After All: A Comparison of Methods for Detecting Amino Acid Sites Under Selection Molecular Biology and Evolution 22(5): 1208-1222

48. Wisotsky SR, Kosakovsky Pond SL, Shank SD, Muse SV. Synonymous Site-to-Site Substitution Rate Variation Dramatically Inflates False Positive Rates of Selection Analyses: Ignore at Your Own Peril. Mol Biol Evol. 2020 Aug 1;37(8):2430-2439. doi: 10.1093/molbev/msaa037. PMID: 32068869; PMCID: PMC7403620.

49. Ben Murrell, Joel O. Wertheim, Sasha Moola, Thomas Weighill, Konrad Scheffler and Sergei L. Kosakovsky Pond (2012) Detecting Individual Sites Subject to Episodic Diversifying Selection PLoS Genetics 8(7): e1002764.

50. M. D. Smith, J. O. Wertheim, S. Weaver, B. Murrell, K. Scheffler and S. L. Kosakovsky Pond Less Is More: An Adaptive Branch-Site Random Effects Model for Efficient Detection of Episodic Diversifying Selection Molecular Biology and Evolution 32: 13421353.

51. Art F. Y. Poon, Fraser I. Lewis, Simon D. W. Frost, Sergei L. Kosakovsky Pond, Spidermonkey: rapid detection of co-evolving sites using Bayesian graphical models, Bioinformatics, Volume 24, Issue 17, 1 September 2008, Pages 1949-1950, https://doi.org/10.1093/bioinformatics/btn313.

52. Wertheim JO, Murrell B, Smith MD, Kosakovsky Pond SL, Scheffler K. RELAX: detecting relaxed selection in a phylogenetic framework. Mol Biol Evol. 2015 Mar;32(3):820-32. doi: 10.1093/molbev/msu400. Epub 2014 Dec 23. PMID: 25540451; PMCID: PMC4327161.

53. Kosakovsky Pond SL, Wisotsky SR, Escalante A, Magalis BR, Weaver S. Contrast-FELA Test for Differences in Selective Pressures at Individual Sites among Clades and Sets of Branches. Mol Biol Evol. 2021 Mar 9;38(3):1184-1198. doi: 10.1093/molbev/msaa263. PMID: 33064823; PMCID: PMC7947784.

54. Lucaci, Alexander G., Sadie R. Wisotsky, Stephen D. Shank, Steven Weaver, and Sergei L. Kosakovsky Pond. "Extra Base Hits: Widespread Empirical Support for Instantaneous Multiple-Nucleotide Changes." PLOS ONE 16, no. 3 (March 12, 2021): e0248337. https://doi.org/10.1371/journal.pone.0248337.

55. Martin, D. \& Rybicki, E. (2000). RDP: detection of recombination amongst aligned sequences. Bioinformatics 16, 562-563.

56. Padidam, M., Sawyer, S. \& Fauquet, C. M. (1999). Possible emergence of new geminiviruses by frequent recombination. Virology 265, 218-225.

57. Posada, D. \& Crandall, K. A. (2001). Evaluation of methods for detecting recombination from DNA sequences: Computer simulations. Proc Natl Acad Sci 98, 13757-13762. 
58. Maynard Smith, J. (1992). Analyzing the mosaic structure of genes. J Mol Evol 34, 126129.

59. Martin, D. P., Posada, D., Crandall, K. A. \& Williamson, C. (2005). A modified bootscan algorithm for automated identification of recombinant sequences and recombination breakpoints. AIDS Res Hum Retroviruses 21, 98-102.

60. Gibbs, M. J., Armstrong, J. S. \& Gibbs, A. J. (2000). Sister-Scanning: a Monte Carlo procedure for assessing signals in recombinant sequences. Bioinformatics 16, 573-582.

61. Lam H.M., Ratmann O., Boni M.F. (2018). Improved algorithmic complexity for the 3 SEQ recombination detection algorithm. Mol Biol Evol, 35, 247-251.

\section{TABLES}

Table 1. Tabulation of Species included in our analysis, comprising NCBI ortholog gene IDs, symbols, mammalian species, common name, and RefSeq accessions.

\begin{tabular}{|c|c|c|c|c|c|c|}
\hline Gene ID & $\begin{array}{c}\text { Gene } \\
\text { symbol }\end{array}$ & Description & $\begin{array}{c}\text { Scientific } \\
\text { name }\end{array}$ & $\begin{array}{c}\text { Common } \\
\text { name }\end{array}$ & $\begin{array}{c}\text { RefSeq } \\
\text { Transcript } \\
\text { accessions }\end{array}$ & $\begin{array}{c}\text { RefSeq } \\
\text { Protein } \\
\text { accessions }\end{array}$ \\
\hline 627 & BDNF & $\begin{array}{c}\text { brain derived } \\
\text { neurotrophic factor }\end{array}$ & Homo sapiens & human & NM_001709.5 & NP_001700.2 \\
\hline 12064 & Bdnf & $\begin{array}{c}\text { brain derived } \\
\text { neurotrophic factor }\end{array}$ & Mus musculus & house mouse & NM_001048142.1 & $\begin{array}{c}\text { NP_00104160 } \\
7.1\end{array}$ \\
\hline 24225 & Bdnf & $\begin{array}{c}\text { brain-derived } \\
\text { neurotrophic factor }\end{array}$ & $\begin{array}{c}\text { Rattus } \\
\text { norvegicus }\end{array}$ & Norway rat & NM_001270630.1 & $\begin{array}{c}\text { NP_00125755 } \\
9.1\end{array}$ \\
\hline 397495 & BDNF & $\begin{array}{c}\text { brain derived } \\
\text { neurotrophic factor }\end{array}$ & Sus scrofa & pig & XM_005654684.3 & $\begin{array}{c}X P \_00565474 \\
1.1\end{array}$ \\
\hline 403461 & BDNF & $\begin{array}{c}\text { brain derived } \\
\text { neurotrophic factor }\end{array}$ & $\begin{array}{l}\text { Canis lupus } \\
\text { familiaris }\end{array}$ & $\operatorname{dog}$ & XM_038429434.1 & $\begin{array}{c}\text { XP_03828536 } \\
2.1\end{array}$ \\
\hline 493690 & BDNF & $\begin{array}{c}\text { brain derived } \\
\text { neurotrophic factor }\end{array}$ & Felis catus & domestic cat & NM_001009828.1 & $\begin{array}{c}\text { NP_00100982 } \\
8.1\end{array}$ \\
\hline 503511 & BDNF & $\begin{array}{c}\text { brain derived } \\
\text { neurotrophic factor }\end{array}$ & Pan troglodytes & chimpanzee & NM_001012441.1 & $\begin{array}{c}\text { NP_00101244 } \\
3.1\end{array}$ \\
\hline 554233 & BDNF & $\begin{array}{c}\text { brain derived } \\
\text { neurotrophic factor }\end{array}$ & $\begin{array}{c}\text { Monodelphis } \\
\text { domestica }\end{array}$ & $\begin{array}{l}\text { gray short- } \\
\text { tailed } \\
\text { opossum }\end{array}$ & XM_007497196.2 & $\begin{array}{c}X P \_00749725 \\
8.1\end{array}$ \\
\hline 617701 & BDNF & $\begin{array}{c}\text { brain derived } \\
\text { neurotrophic factor }\end{array}$ & Bos taurus & cattle & XM_005216334.4 & $\begin{array}{c}\text { XP_00521639 } \\
1.1\end{array}$ \\
\hline
\end{tabular}


bioRxiv preprint doi: https://doi.org/10.1101/2022.01.21.477254; this version posted January 21, 2022. The copyright holder for this preprint (which was not certified by peer review) is the author/funder, who has granted bioRxiv a license to display the preprint in perpetuity. It is made available under aCC-BY-NC-ND 4.0 International license.

\begin{tabular}{|c|c|c|c|c|c|c|}
\hline 701245 & BDNF & $\begin{array}{c}\text { brain derived } \\
\text { neurotrophic factor }\end{array}$ & Macaca mulatta & $\begin{array}{l}\text { Rhesus } \\
\text { monkey }\end{array}$ & XM_015114598.2 & $\begin{array}{c}X P \_01497008 \\
4.1\end{array}$ \\
\hline 100009689 & BDNF & $\begin{array}{c}\text { brain derived } \\
\text { neurotrophic factor }\end{array}$ & Equus caballus & horse & NM_001081787.1 & $\begin{array}{c}\text { NP_00107525 } \\
6.1\end{array}$ \\
\hline 100081142 & BDNF & $\begin{array}{c}\text { brain derived } \\
\text { neurotrophic factor }\end{array}$ & $\begin{array}{l}\text { Ornithorhynchus } \\
\text { anatinus }\end{array}$ & platypus & XM_029059317.2 & $\begin{array}{c}\text { XP_02891515 } \\
0.1\end{array}$ \\
\hline 100356949 & BDNF & $\begin{array}{c}\text { brain derived } \\
\text { neurotrophic factor }\end{array}$ & $\begin{array}{l}\text { Oryctolagus } \\
\text { cuniculus }\end{array}$ & rabbit & XM_017345633.1 & $\begin{array}{c}\text { XP_01720112 } \\
2.1\end{array}$ \\
\hline 100409412 & BDNF & $\begin{array}{c}\text { brain derived } \\
\text { neurotrophic factor }\end{array}$ & $\begin{array}{l}\text { Callithrix } \\
\text { jacchus }\end{array}$ & $\begin{array}{l}\text { white-tufted- } \\
\text { ear marmoset }\end{array}$ & XM_009007854.3 & $\begin{array}{c}\text { XP_00900610 } \\
2.1\end{array}$ \\
\hline 100447350 & BDNF & $\begin{array}{c}\text { brain derived } \\
\text { neurotrophic factor }\end{array}$ & Pongo abelii & $\begin{array}{l}\text { Sumatran } \\
\text { orangutan }\end{array}$ & XM_002821931.2 & $\begin{array}{c}\text { XP_00282197 } \\
7.1\end{array}$ \\
\hline 100467162 & BDNF & $\begin{array}{c}\text { brain derived } \\
\text { neurotrophic factor }\end{array}$ & $\begin{array}{l}\text { Ailuropoda } \\
\text { melanoleuca }\end{array}$ & giant panda & XM_011226480.3 & $\begin{array}{c}\text { XP_o1122478 } \\
2.2\end{array}$ \\
\hline 100594402 & BDNF & $\begin{array}{c}\text { brain derived } \\
\text { neurotrophic factor }\end{array}$ & $\begin{array}{l}\text { Nomascus } \\
\text { leucogenys }\end{array}$ & $\begin{array}{c}\text { northern } \\
\text { white-cheeked } \\
\text { gibbon }\end{array}$ & XM_003254347.2 & $\begin{array}{c}X P \_00325439 \\
5.1\end{array}$ \\
\hline 100667885 & BDNF & $\begin{array}{c}\text { brain derived } \\
\text { neurotrophic factor }\end{array}$ & $\begin{array}{l}\text { Loxodonta } \\
\text { africana }\end{array}$ & $\begin{array}{l}\text { African } \\
\text { savanna } \\
\text { elephant }\end{array}$ & XM_023550772.1 & $\begin{array}{c}\text { XP_02340654 } \\
0.1\end{array}$ \\
\hline 100730257 & Bdnf & $\begin{array}{c}\text { brain derived } \\
\text { neurotrophic factor }\end{array}$ & Cavia porcellus & $\begin{array}{l}\text { domestic } \\
\text { guinea pig }\end{array}$ & XM_013147262.2 & $\begin{array}{c}X P \_01300271 \\
6.1\end{array}$ \\
\hline 100768664 & Bdnf & $\begin{array}{c}\text { brain derived } \\
\text { neurotrophic factor }\end{array}$ & $\begin{array}{l}\text { Cricetulus } \\
\text { griseus }\end{array}$ & $\begin{array}{l}\text { Chinese } \\
\text { hamster }\end{array}$ & XM_007653166.4 & $\begin{array}{c}X P \_00765135 \\
6.1\end{array}$ \\
\hline 100934810 & BDNF & $\begin{array}{c}\text { brain derived } \\
\text { neurotrophic factor }\end{array}$ & $\begin{array}{l}\text { Sarcophilus } \\
\text { harrisii }\end{array}$ & $\begin{array}{c}\text { Tasmanian } \\
\text { devil }\end{array}$ & XM_031944159.1 & $\begin{array}{c}\text { XP_03180001 } \\
9.1\end{array}$ \\
\hline 100958946 & BDNF & $\begin{array}{c}\text { brain derived } \\
\text { neurotrophic factor }\end{array}$ & $\begin{array}{l}\text { Otolemur } \\
\text { garnettii }\end{array}$ & $\begin{array}{l}\text { small-eared } \\
\text { galago }\end{array}$ & XM_012814047.1 & $\begin{array}{c}X P \_01266950 \\
1.1\end{array}$ \\
\hline 100983866 & BDNF & $\begin{array}{c}\text { brain derived } \\
\text { neurotrophic factor }\end{array}$ & Pan paniscus & $\begin{array}{c}\text { pygmy } \\
\text { chimpanzee }\end{array}$ & XM_034932318.1 & $\begin{array}{c}\text { XP_03478820 } \\
9.1\end{array}$ \\
\hline 101007866 & BDNF & $\begin{array}{c}\text { brain derived } \\
\text { neurotrophic factor }\end{array}$ & Papio anubis & olive baboon & XM_017948537.3 & $\begin{array}{c}X P \_01780402 \\
6.1\end{array}$ \\
\hline 101037414 & BDNF & $\begin{array}{c}\text { brain derived } \\
\text { neurotrophic factor }\end{array}$ & $\begin{array}{c}\text { Saimiri } \\
\text { boliviensis }\end{array}$ & $\begin{array}{l}\text { Bolivian } \\
\text { squirrel } \\
\text { monkey }\end{array}$ & XM_003919940.3 & $\begin{array}{c}X P \_00391998 \\
9.2\end{array}$ \\
\hline
\end{tabular}


bioRxiv preprint doi: https://doi.org/10.1101/2022.01.21.477254; this version posted January 21, 2022. The copyright holder for this preprint (which was not certified by peer review) is the author/funder, who has granted bioRxiv a license to display the preprint in perpetuity. It is made available under aCC-BY-NC-ND 4.0 International license.

\begin{tabular}{|c|c|c|c|c|c|c|}
\hline 101117275 & BDNF & $\begin{array}{c}\text { brain derived } \\
\text { neurotrophic factor }\end{array}$ & Ovis aries & sheep & XM_012096129.4 & $\begin{array}{c}X P \_01195151 \\
9.2\end{array}$ \\
\hline 101134399 & BDNF & $\begin{array}{c}\text { brain derived } \\
\text { neurotrophic factor }\end{array}$ & Gorilla gorilla & western gorilla & XM_004050851.2 & $\begin{array}{c}X P \_00405089 \\
9.1\end{array}$ \\
\hline 101281702 & BDNF & $\begin{array}{c}\text { brain derived } \\
\text { neurotrophic factor }\end{array}$ & Orcinus orca & killer whale & XM_004263941.3 & $\begin{array}{c}X P \_00426398 \\
9.1\end{array}$ \\
\hline 101338565 & BDNF & $\begin{array}{c}\text { brain derived } \\
\text { neurotrophic factor }\end{array}$ & $\begin{array}{l}\text { Tursiops } \\
\text { truncatus }\end{array}$ & $\begin{array}{l}\text { common } \\
\text { bottlenose } \\
\text { dolphin }\end{array}$ & XM_019947883.2 & $\begin{array}{c}X P \_01980344 \\
2.1\end{array}$ \\
\hline 101350169 & $\begin{array}{c}\text { LOC } 1013 \\
50169\end{array}$ & $\begin{array}{c}\text { brain derived } \\
\text { neurotrophic factor }\end{array}$ & $\begin{array}{l}\text { Trichechus } \\
\text { manatus } \\
\text { latirostris }\end{array}$ & $\begin{array}{c}\text { Florida } \\
\text { manatee }\end{array}$ & XM_004369733.1 & $\begin{array}{c}X P \_00436979 \\
0.1\end{array}$ \\
\hline 101372507 & BDNF & $\begin{array}{c}\text { brain derived } \\
\text { neurotrophic factor }\end{array}$ & $\begin{array}{l}\text { Odobenus } \\
\text { rosmarus } \\
\text { divergens }\end{array}$ & Pacific walrus & XM_004408653.1 & $\begin{array}{c}\text { XP_00440871 } \\
0.1\end{array}$ \\
\hline 101398458 & $\begin{array}{l}\text { LOC } 1013 \\
98458\end{array}$ & $\begin{array}{c}\text { brain derived } \\
\text { neurotrophic factor }\end{array}$ & $\begin{array}{l}\text { Ceratotherium } \\
\text { simum simum }\end{array}$ & $\begin{array}{l}\text { southern white } \\
\text { rhinoceros }\end{array}$ & XM_004418542.2 & $\begin{array}{c}X P \_00441859 \\
9.1\end{array}$ \\
\hline 101428552 & BDNF & $\begin{array}{c}\text { brain derived } \\
\text { neurotrophic factor }\end{array}$ & $\begin{array}{c}\text { Dasypus } \\
\text { novemcinctus }\end{array}$ & $\begin{array}{l}\text { nine-banded } \\
\text { armadillo }\end{array}$ & XM_012523604.2 & $\begin{array}{c}\text { XP_01237905 } \\
8.1\end{array}$ \\
\hline 101528222 & BDNF & $\begin{array}{c}\text { brain derived } \\
\text { neurotrophic factor }\end{array}$ & $\begin{array}{l}\text { Ochotona } \\
\text { princeps }\end{array}$ & American pika & XM_004585440.1 & $\begin{array}{c}X P \_00458549 \\
7.1\end{array}$ \\
\hline 101553155 & BDNF & $\begin{array}{c}\text { brain derived } \\
\text { neurotrophic factor }\end{array}$ & Sorex araneus & $\begin{array}{c}\text { European } \\
\text { shrew }\end{array}$ & XM_004607860.1 & $\begin{array}{c}X P \_00460791 \\
7.1\end{array}$ \\
\hline 101566518 & Bdnf & $\begin{array}{c}\text { brain derived } \\
\text { neurotrophic factor }\end{array}$ & Octodon degus & degu & XM_004644113.2 & $\begin{array}{c}X P \_00464417 \\
0.1\end{array}$ \\
\hline 101600646 & Bdnf & $\begin{array}{c}\text { brain derived } \\
\text { neurotrophic factor }\end{array}$ & Jaculus jaculus & $\begin{array}{l}\text { lesser } \\
\text { Egyptian } \\
\text { jerboa }\end{array}$ & XM_004660846.2 & $\begin{array}{c}X P \_00466090 \\
3.1\end{array}$ \\
\hline 101632951 & BDNF & $\begin{array}{c}\text { brain derived } \\
\text { neurotrophic factor }\end{array}$ & $\begin{array}{l}\text { Condylura } \\
\text { cristata }\end{array}$ & $\begin{array}{l}\text { star-nosed } \\
\text { mole }\end{array}$ & XM_004682964.2 & $\begin{array}{c}X P \_00468302 \\
1.1\end{array}$ \\
\hline 101643198 & BDNF & $\begin{array}{c}\text { brain derived } \\
\text { neurotrophic factor }\end{array}$ & Echinops telfairi & $\begin{array}{c}\text { small } \\
\text { Madagascar } \\
\text { hedgehog }\end{array}$ & XM_004708253.2 & $\begin{array}{c}\text { XP_00470831 } \\
0.1\end{array}$ \\
\hline 101687038 & BDNF & $\begin{array}{c}\text { brain derived } \\
\text { neurotrophic factor }\end{array}$ & $\begin{array}{l}\text { Mustela putorius } \\
\text { furo }\end{array}$ & $\begin{array}{l}\text { domestic } \\
\text { ferret }\end{array}$ & XM_004755891.2 & $\begin{array}{c}X P \_00475594 \\
8.1\end{array}$ \\
\hline 101704465 & Bdnf & $\begin{array}{c}\text { brain derived } \\
\text { neurotrophic factor }\end{array}$ & $\begin{array}{l}\text { Heterocephalus } \\
\text { glaber }\end{array}$ & $\begin{array}{l}\text { naked mole- } \\
\text { rat }\end{array}$ & XM_004851581.3 & $\begin{array}{c}X P \_00485163 \\
8.1\end{array}$ \\
\hline
\end{tabular}


bioRxiv preprint doi: https://doi.org/10.1101/2022.01.21.477254; this version posted January 21, 2022. The copyright holder for this preprint (which was not certified by peer review) is the author/funder, who has granted bioRxiv a license to display the preprint in perpetuity. It is made available under aCC-BY-NC-ND 4.0 International license.

\begin{tabular}{|c|c|c|c|c|c|c|}
\hline 101837384 & Bdnf & $\begin{array}{c}\text { brain derived } \\
\text { neurotrophic factor }\end{array}$ & $\begin{array}{l}\text { Mesocricetus } \\
\text { auratus }\end{array}$ & $\begin{array}{l}\text { golden } \\
\text { hamster }\end{array}$ & XM_005064810.4 & $\begin{array}{c}X P \_00506486 \\
7.1\end{array}$ \\
\hline 101954451 & Bdnf & $\begin{array}{c}\text { brain derived } \\
\text { neurotrophic factor }\end{array}$ & $\begin{array}{c}\text { Ictidomys } \\
\text { tridecemlineatus }\end{array}$ & $\begin{array}{l}\text { thirteen-lined } \\
\text { ground } \\
\text { squirrel }\end{array}$ & XM_040284582.1 & $\begin{array}{c}\text { XP_04014051 } \\
6.1\end{array}$ \\
\hline 101993181 & Bdnf & $\begin{array}{c}\text { brain derived } \\
\text { neurotrophic factor }\end{array}$ & $\begin{array}{l}\text { Microtus } \\
\text { ochrogaster }\end{array}$ & prairie vole & XM_005364052.2 & $\begin{array}{c}X P \_00536410 \\
9.1\end{array}$ \\
\hline 102016703 & Bdnf & $\begin{array}{c}\text { brain derived } \\
\text { neurotrophic factor }\end{array}$ & $\begin{array}{l}\text { Chinchilla } \\
\text { lanigera }\end{array}$ & $\begin{array}{l}\text { long-tailed } \\
\text { chinchilla }\end{array}$ & XM_005401751.2 & $\begin{array}{c}\text { XP_00540180 } \\
8.1\end{array}$ \\
\hline 102126294 & BDNF & $\begin{array}{c}\text { brain derived } \\
\text { neurotrophic factor }\end{array}$ & $\begin{array}{c}\text { Macaca } \\
\text { fascicularis }\end{array}$ & $\begin{array}{l}\text { crab-eating } \\
\text { macaque }\end{array}$ & XM_005578346.2 & $\begin{array}{c}X P \_00557840 \\
3.1\end{array}$ \\
\hline 102180782 & BDNF & $\begin{array}{c}\text { brain derived } \\
\text { neurotrophic factor }\end{array}$ & Capra hircus & goat & XM_005690025.2 & $\begin{array}{c}\text { XP_00569008 } \\
2.2\end{array}$ \\
\hline 102247090 & BDNF & $\begin{array}{c}\text { brain derived } \\
\text { neurotrophic factor }\end{array}$ & Myotis brandtii & Brandt's bat & XM_014545223.1 & $\begin{array}{c}\text { XP_01440070 } \\
9.1\end{array}$ \\
\hline 102279714 & BDNF & $\begin{array}{c}\text { brain derived } \\
\text { neurotrophic factor }\end{array}$ & Bos mutus & wild yak & XM_005890667.2 & $\begin{array}{c}\text { XP_00589072 } \\
9.1\end{array}$ \\
\hline 102395046 & BDNF & $\begin{array}{c}\text { brain derived } \\
\text { neurotrophic factor }\end{array}$ & Bubalus bubalis & water buffalo & XM_006068006.2 & $\begin{array}{c}X P \_00606806 \\
8.1\end{array}$ \\
\hline 102440705 & BDNF & $\begin{array}{c}\text { brain derived } \\
\text { neurotrophic factor }\end{array}$ & Myotis lucifugus & little brown bat & XM_023756374.1 & $\begin{array}{c}\mathrm{XP} \_02361214 \\
2.1\end{array}$ \\
\hline 102475289 & BDNF & $\begin{array}{c}\text { brain derived } \\
\text { neurotrophic factor }\end{array}$ & $\begin{array}{l}\text { Tupaia } \\
\text { chinensis }\end{array}$ & $\begin{array}{c}\text { Chinese tree } \\
\text { shrew }\end{array}$ & XM_014591303.2 & $\begin{array}{c}\text { XP_01444678 } \\
9.1\end{array}$ \\
\hline 102511705 & BDNF & $\begin{array}{c}\text { brain derived } \\
\text { neurotrophic factor }\end{array}$ & Camelus ferus & $\begin{array}{l}\text { Wild Bactrian } \\
\text { camel }\end{array}$ & XM_006195083.3 & $\begin{array}{c}\text { XP_00619514 } \\
5.1\end{array}$ \\
\hline 102532564 & BDNF & $\begin{array}{c}\text { brain derived } \\
\text { neurotrophic factor }\end{array}$ & Vicugna pacos & alpaca & XM_031681074.1 & $\begin{array}{c}X P \_03153693 \\
4.1\end{array}$ \\
\hline 102730927 & BDNF & $\begin{array}{c}\text { brain derived } \\
\text { neurotrophic factor }\end{array}$ & $\begin{array}{l}\text { Leptonychotes } \\
\text { weddellii }\end{array}$ & Weddell seal & XM_031025064.1 & $\begin{array}{c}\text { XP_03088092 } \\
4.1\end{array}$ \\
\hline 102754946 & BDNF & $\begin{array}{c}\text { brain derived } \\
\text { neurotrophic factor }\end{array}$ & Myotis davidii & & XM_006753948.2 & $\begin{array}{c}X P \_00675401 \\
1.1\end{array}$ \\
\hline 102839210 & BDNF & $\begin{array}{c}\text { brain derived } \\
\text { neurotrophic factor }\end{array}$ & $\begin{array}{l}\text { Chrysochloris } \\
\text { asiatica }\end{array}$ & $\begin{array}{l}\text { Cape golden } \\
\text { mole }\end{array}$ & XM_006864851.1 & $\begin{array}{c}X P \_00686491 \\
3.1\end{array}$ \\
\hline 102870215 & BDNF & $\begin{array}{c}\text { brain derived } \\
\text { neurotrophic factor }\end{array}$ & $\begin{array}{l}\text { Elephantulus } \\
\text { edwardii }\end{array}$ & $\begin{array}{l}\text { Cape elephant } \\
\text { shrew }\end{array}$ & XM_006883713.1 & $\begin{array}{c}X P \_00688377 \\
5.1\end{array}$ \\
\hline
\end{tabular}


bioRxiv preprint doi: https://doi.org/10.1101/2022.01.21.477254; this version posted January 21, 2022. The copyright holder for this preprint (which was not certified by peer review) is the author/funder, who has granted bioRxiv a license to display the preprint in perpetuity. It is made available under aCC-BY-NC-ND 4.0 International license.

\begin{tabular}{|c|c|c|c|c|c|c|}
\hline 102896087 & BDNF & $\begin{array}{c}\text { brain derived } \\
\text { neurotrophic factor }\end{array}$ & Pteropus alecto & $\begin{array}{l}\text { black flying } \\
\text { fox }\end{array}$ & XM_006907988.2 & $\begin{array}{c}X P \_00690805 \\
0.1\end{array}$ \\
\hline 102911929 & Bdnf & $\begin{array}{c}\text { brain derived } \\
\text { neurotrophic factor }\end{array}$ & $\begin{array}{c}\text { Peromyscus } \\
\text { maniculatus } \\
\text { bairdii }\end{array}$ & $\begin{array}{l}\text { prairie deer } \\
\text { mouse }\end{array}$ & XM_006980818.2 & $\begin{array}{c}X P \_00698088 \\
0.1\end{array}$ \\
\hline 102958723 & BDNF & $\begin{array}{c}\text { brain derived } \\
\text { neurotrophic factor }\end{array}$ & $\begin{array}{l}\text { Panthera tigris } \\
\text { altaica }\end{array}$ & Amur tiger & XM_015544869.1 & $\begin{array}{c}X P \_01540035 \\
5.1\end{array}$ \\
\hline 102977934 & BDNF & $\begin{array}{c}\text { brain derived } \\
\text { neurotrophic factor }\end{array}$ & $\begin{array}{l}\text { Physeter } \\
\text { catodon }\end{array}$ & sperm whale & XM_028501134.1 & $\begin{array}{c}X P \_02835693 \\
5.1\end{array}$ \\
\hline 103017938 & BDNF & $\begin{array}{c}\text { brain derived } \\
\text { neurotrophic factor }\end{array}$ & \multicolumn{2}{|c|}{$\begin{array}{l}\text { Balaenoptera acutorostrata } \\
\text { scammoni }\end{array}$} & XM_007180991.1 & $\begin{array}{c}X P \_00718105 \\
3.1\end{array}$ \\
\hline 103085069 & BDNF & $\begin{array}{c}\text { brain derived } \\
\text { neurotrophic factor }\end{array}$ & Lipotes vexillifer & $\begin{array}{l}\text { Yangtze River } \\
\text { dolphin }\end{array}$ & XM_007461679.1 & $\begin{array}{c}X P \_00746174 \\
1.1\end{array}$ \\
\hline 103126099 & BDNF & $\begin{array}{c}\text { brain derived } \\
\text { neurotrophic factor }\end{array}$ & $\begin{array}{l}\text { Erinaceus } \\
\text { europaeus }\end{array}$ & $\begin{array}{l}\text { western } \\
\text { European } \\
\text { hedgehog }\end{array}$ & XM_016194241.1 & $\begin{array}{c}X P \_01604972 \\
7.1\end{array}$ \\
\hline 103206496 & BDNF & $\begin{array}{c}\text { brain derived } \\
\text { neurotrophic factor }\end{array}$ & $\begin{array}{l}\text { Orycteropus afer } \\
\text { afer }\end{array}$ & & XM_007951952.1 & $\begin{array}{c}X P \_00795014 \\
3.1\end{array}$ \\
\hline 103238537 & BDNF & $\begin{array}{c}\text { brain derived } \\
\text { neurotrophic factor }\end{array}$ & $\begin{array}{l}\text { Chlorocebus } \\
\text { sabaeus }\end{array}$ & green monkey & XM_008003703.2 & $\begin{array}{c}X P \_00800189 \\
4.1\end{array}$ \\
\hline 103252117 & BDNF & $\begin{array}{c}\text { brain derived } \\
\text { neurotrophic factor }\end{array}$ & Carlito syrichta & $\begin{array}{l}\text { Philippine } \\
\text { tarsier }\end{array}$ & XM_008050727.1 & $\begin{array}{c}X P \_00804891 \\
8.1\end{array}$ \\
\hline 103292699 & BDNF & $\begin{array}{c}\text { brain derived } \\
\text { neurotrophic factor }\end{array}$ & $\begin{array}{l}\text { Eptesicus } \\
\text { fuscus }\end{array}$ & big brown bat & XM_008148947.2 & $\begin{array}{c}X P \_00814716 \\
9.1\end{array}$ \\
\hline 103552694 & BDNF & $\begin{array}{c}\text { brain derived } \\
\text { neurotrophic factor }\end{array}$ & $\begin{array}{l}\text { Equus } \\
\text { przewalskii }\end{array}$ & $\begin{array}{l}\text { Przewalski's } \\
\text { horse }\end{array}$ & XM_008522855.1 & $\begin{array}{c}X P \_00852107 \\
7.1\end{array}$ \\
\hline 103599960 & BDNF & $\begin{array}{c}\text { brain derived } \\
\text { neurotrophic factor }\end{array}$ & $\begin{array}{l}\text { Galeopterus } \\
\text { variegatus }\end{array}$ & $\begin{array}{l}\text { Sunda flying } \\
\text { lemur }\end{array}$ & XM_008584165.1 & $\begin{array}{c}X P \_00858238 \\
7.1\end{array}$ \\
\hline 103659367 & BDNF & $\begin{array}{c}\text { brain derived } \\
\text { neurotrophic factor }\end{array}$ & Ursus maritimus & polar bear & XM_008686880.2 & $\begin{array}{c}X P \_00868510 \\
2.2\end{array}$ \\
\hline 103748489 & Bdnf & $\begin{array}{c}\text { brain derived } \\
\text { neurotrophic factor }\end{array}$ & $\begin{array}{c}\text { Nannospalax } \\
\text { galili }\end{array}$ & $\begin{array}{l}\text { Upper Galilee } \\
\text { mountains } \\
\text { blind mole rat }\end{array}$ & XM_029555090.1 & $\begin{array}{c}X P \_02941095 \\
0.1\end{array}$ \\
\hline 104671126 & BDNF & $\begin{array}{c}\text { brain derived } \\
\text { neurotrophic factor }\end{array}$ & $\begin{array}{l}\text { Rhinopithecus } \\
\text { roxellana }\end{array}$ & $\begin{array}{l}\text { golden snub- } \\
\text { nosed monkey }\end{array}$ & XM_010374529.2 & $\begin{array}{c}X P \_01037283 \\
1.1\end{array}$ \\
\hline
\end{tabular}


bioRxiv preprint doi: https://doi.org/10.1101/2022.01.21.477254; this version posted January 21, 2022. The copyright holder for this preprint (which was not certified by peer review) is the author/funder, who has granted bioRxiv a license to display the preprint in perpetuity. It is made available under aCC-BY-NC-ND 4.0 International license.

\begin{tabular}{|c|c|c|c|c|c|c|}
\hline 104873642 & Bdnf & $\begin{array}{c}\text { brain derived } \\
\text { neurotrophic factor }\end{array}$ & $\begin{array}{l}\text { Fukomys } \\
\text { damarensis }\end{array}$ & $\begin{array}{c}\text { Damara mole- } \\
\text { rat }\end{array}$ & XM_033764060.1 & $\begin{array}{c}\text { XP_03361995 } \\
1.1\end{array}$ \\
\hline 104982427 & BDNF & $\begin{array}{c}\text { brain derived } \\
\text { neurotrophic factor }\end{array}$ & $\begin{array}{l}\text { Bison bison } \\
\text { bison }\end{array}$ & & XM_010831788.1 & $\begin{array}{c}X P \_01083009 \\
0.1\end{array}$ \\
\hline 105076551 & BDNF & $\begin{array}{c}\text { brain derived } \\
\text { neurotrophic factor }\end{array}$ & $\begin{array}{c}\text { Camelus } \\
\text { bactrianus }\end{array}$ & $\begin{array}{c}\text { Bactrian } \\
\text { camel }\end{array}$ & XM_010964743.1 & $\begin{array}{c}\text { XP_01096304 } \\
5.1\end{array}$ \\
\hline 105106448 & BDNF & $\begin{array}{c}\text { brain derived } \\
\text { neurotrophic factor }\end{array}$ & $\begin{array}{c}\text { Camelus } \\
\text { dromedarius }\end{array}$ & Arabian camel & XM_031459858.1 & $\begin{array}{c}\text { XP_03131571 } \\
8.1\end{array}$ \\
\hline 105293721 & BDNF & $\begin{array}{c}\text { brain derived } \\
\text { neurotrophic factor }\end{array}$ & $\begin{array}{l}\text { Pteropus } \\
\text { vampyrus }\end{array}$ & large flying fox & XM_011362565.2 & $\begin{array}{c}X P \_01136086 \\
7.1\end{array}$ \\
\hline 105463281 & BDNF & $\begin{array}{c}\text { brain derived } \\
\text { neurotrophic factor }\end{array}$ & $\begin{array}{c}\text { Macaca } \\
\text { nemestrina }\end{array}$ & $\begin{array}{l}\text { pig-tailed } \\
\text { macaque }\end{array}$ & XM_011710310.2 & $\begin{array}{c}X P \_01170861 \\
2.1\end{array}$ \\
\hline 105507710 & BDNF & $\begin{array}{c}\text { brain derived } \\
\text { neurotrophic factor }\end{array}$ & \multicolumn{2}{|c|}{ Colobus angolensis palliatus } & XM_011936307.1 & $\begin{array}{c}\text { XP_01179169 } \\
7.1\end{array}$ \\
\hline 105528120 & BDNF & $\begin{array}{c}\text { brain derived } \\
\text { neurotrophic factor }\end{array}$ & $\begin{array}{c}\text { Mandrillus } \\
\text { leucophaeus }\end{array}$ & drill & XM_011964715.1 & $\begin{array}{c}X P \_01182010 \\
5.1\end{array}$ \\
\hline 105572781 & BDNF & $\begin{array}{c}\text { brain derived } \\
\text { neurotrophic factor }\end{array}$ & Cercocebus atys & $\begin{array}{c}\text { sooty } \\
\text { mangabey }\end{array}$ & XM_012031697.1 & $\begin{array}{c}X P \_01188708 \\
7.1\end{array}$ \\
\hline 105717219 & BDNF & $\begin{array}{c}\text { brain derived } \\
\text { neurotrophic factor }\end{array}$ & $\begin{array}{c}\text { Aotus } \\
\text { nancymaae }\end{array}$ & $\begin{array}{l}\text { Ma's night } \\
\text { monkey }\end{array}$ & XM_012452238.1 & $\begin{array}{c}\text { XP_01230766 } \\
1.1\end{array}$ \\
\hline 105814556 & BDNF & $\begin{array}{c}\text { brain derived } \\
\text { neurotrophic factor }\end{array}$ & $\begin{array}{c}\text { Propithecus } \\
\text { coquereli }\end{array}$ & $\begin{array}{l}\text { Coquerel's } \\
\text { sifaka }\end{array}$ & XM_012649556.1 & $\begin{array}{c}X P \_01250501 \\
0.1\end{array}$ \\
\hline 105860148 & BDNF & $\begin{array}{c}\text { brain derived } \\
\text { neurotrophic factor }\end{array}$ & $\begin{array}{l}\text { Microcebus } \\
\text { murinus }\end{array}$ & $\begin{array}{l}\text { gray mouse } \\
\text { lemur }\end{array}$ & XM_020286534.1 & $\begin{array}{c}\text { XP_02014212 } \\
3.1\end{array}$ \\
\hline 105988089 & Bdnf & $\begin{array}{c}\text { brain derived } \\
\text { neurotrophic factor }\end{array}$ & Dipodomys ordii & $\begin{array}{c}\text { Ord's } \\
\text { kangaroo rat }\end{array}$ & XM_013019592.1 & $\begin{array}{c}X P \_01287504 \\
6.1\end{array}$ \\
\hline 106824927 & BDNF & $\begin{array}{c}\text { brain derived } \\
\text { neurotrophic factor }\end{array}$ & Equus asinus & ass & XM_014831462.1 & $\begin{array}{c}\text { XP_01468694 } \\
8.1\end{array}$ \\
\hline 106970278 & BDNF & $\begin{array}{c}\text { brain derived } \\
\text { neurotrophic factor }\end{array}$ & $\begin{array}{l}\text { Acinonyx } \\
\text { jubatus }\end{array}$ & cheetah & XM_027072960.1 & $\begin{array}{c}X P \_02692876 \\
1.1\end{array}$ \\
\hline 107134338 & Bdnf & $\begin{array}{c}\text { brain derived } \\
\text { neurotrophic factor }\end{array}$ & $\begin{array}{l}\text { Marmota } \\
\text { marmota } \\
\text { marmota }\end{array}$ & Alpine marmot & XM_015476449.1 & $\begin{array}{c}X P \_01533193 \\
5.1\end{array}$ \\
\hline 107512170 & BDNF & $\begin{array}{c}\text { brain derived } \\
\text { neurotrophic factor }\end{array}$ & $\begin{array}{l}\text { Rousettus } \\
\text { aegyptiacus }\end{array}$ & $\begin{array}{l}\text { Egyptian } \\
\text { rousette }\end{array}$ & XM_036221046.1 & $\begin{array}{c}\text { XP_03607693 } \\
9.1\end{array}$ \\
\hline
\end{tabular}


bioRxiv preprint doi: https://doi.org/10.1101/2022.01.21.477254; this version posted January 21, 2022. The copyright holder for this preprint (which was not certified by peer review) is the author/funder, who has granted bioRxiv a license to display the preprint in perpetuity. It is made available under aCC-BY-NC-ND 4.0 International license.

\begin{tabular}{|c|c|c|c|c|c|c|}
\hline 107531942 & BDNF & $\begin{array}{c}\text { brain derived } \\
\text { neurotrophic factor }\end{array}$ & $\begin{array}{l}\text { Miniopterus } \\
\text { natalensis }\end{array}$ & & XM_016206154.1 & $\begin{array}{c}\text { XP_01606164 } \\
0.1\end{array}$ \\
\hline 108311306 & BDNF & $\begin{array}{c}\text { brain derived } \\
\text { neurotrophic factor }\end{array}$ & Cebus imitator & $\begin{array}{l}\text { Panamanian } \\
\text { white-faced } \\
\text { capuchin }\end{array}$ & XM_017538722.1 & $\begin{array}{c}\text { XP_01739421 } \\
1.1\end{array}$ \\
\hline 108401589 & BDNF & $\begin{array}{c}\text { brain derived } \\
\text { neurotrophic factor }\end{array}$ & Manis javanica & $\begin{array}{l}\text { Malayan } \\
\text { pangolin }\end{array}$ & XM_017667612.2 & $\begin{array}{c}\text { XP_01752310 } \\
1.2\end{array}$ \\
\hline 108519651 & BDNF & $\begin{array}{c}\text { brain derived } \\
\text { neurotrophic factor }\end{array}$ & $\begin{array}{l}\text { Rhinopithecus } \\
\text { bieti }\end{array}$ & $\begin{array}{l}\text { black snub- } \\
\text { nosed monkey }\end{array}$ & XM_017858805.1 & $\begin{array}{c}\text { XP_01771429 } \\
4.1\end{array}$ \\
\hline 109271282 & BDNF & $\begin{array}{c}\text { brain derived } \\
\text { neurotrophic factor }\end{array}$ & Panthera pardus & leopard & XM_019456577.1 & $\begin{array}{c}\text { XP_01931212 } \\
2.1\end{array}$ \\
\hline 109387036 & BDNF & $\begin{array}{c}\text { brain derived } \\
\text { neurotrophic factor }\end{array}$ & $\begin{array}{l}\text { Hipposideros } \\
\text { armiger }\end{array}$ & $\begin{array}{c}\text { great } \\
\text { roundleaf bat }\end{array}$ & XM_019650718.1 & $\begin{array}{c}\text { XP_01950626 } \\
3.1\end{array}$ \\
\hline 109569212 & BDNF & $\begin{array}{c}\text { brain derived } \\
\text { neurotrophic factor }\end{array}$ & Bos indicus & zebu cattle & XM_019974522.1 & $\begin{array}{c}X P \_01983008 \\
1.1\end{array}$ \\
\hline 109695020 & Bdnf & $\begin{array}{c}\text { brain derived } \\
\text { neurotrophic factor }\end{array}$ & $\begin{array}{c}\text { Castor } \\
\text { canadensis }\end{array}$ & $\begin{array}{l}\text { American } \\
\text { beaver }\end{array}$ & XM_020177315.1 & $\begin{array}{c}\text { XP_02003290 } \\
4.1\end{array}$ \\
\hline 110143608 & BDNF & $\begin{array}{c}\text { brain derived } \\
\text { neurotrophic factor }\end{array}$ & \multicolumn{2}{|c|}{ Odocoileus virginianus texanus } & XM_020903256.1 & $\begin{array}{c}X P \_02075891 \\
5.1\end{array}$ \\
\hline 110202027 & BDNF & $\begin{array}{c}\text { brain derived } \\
\text { neurotrophic factor }\end{array}$ & $\begin{array}{l}\text { Phascolarctos } \\
\text { cinereus }\end{array}$ & koala & XM_020977976.1 & $\begin{array}{c}\text { XP_02083363 } \\
5.1\end{array}$ \\
\hline 110285237 & Bdnf & $\begin{array}{c}\text { brain derived } \\
\text { neurotrophic factor }\end{array}$ & Mus caroli & $\begin{array}{l}\text { Ryukyu } \\
\text { mouse }\end{array}$ & XM_021151236.2 & $\begin{array}{c}\text { XP_02100689 } \\
5.1\end{array}$ \\
\hline 110318089 & Bdnf & $\begin{array}{c}\text { brain derived } \\
\text { neurotrophic factor }\end{array}$ & Mus pahari & shrew mouse & XM_021192829.2 & $\begin{array}{c}X P \_02104848 \\
8.1\end{array}$ \\
\hline 110576669 & BDNF & $\begin{array}{c}\text { brain derived } \\
\text { neurotrophic factor }\end{array}$ & $\begin{array}{l}\text { Neomonachus } \\
\text { schauinslandi }\end{array}$ & $\begin{array}{l}\text { Hawaiian } \\
\text { monk seal }\end{array}$ & XM_021685880.1 & $\begin{array}{c}\text { XP_02154155 } \\
5.1\end{array}$ \\
\hline 111150176 & $\begin{array}{c}\text { LOC } 1111 \\
50176\end{array}$ & $\begin{array}{c}\text { brain derived } \\
\text { neurotrophic factor }\end{array}$ & $\begin{array}{c}\text { Enhydra lutris } \\
\text { kenyoni }\end{array}$ & & XM_022507574.1 & $\begin{array}{c}\text { XP_02236328 } \\
2.1\end{array}$ \\
\hline 111179820 & BDNF & $\begin{array}{c}\text { brain derived } \\
\text { neurotrophic factor }\end{array}$ & $\begin{array}{l}\text { Delphinapterus } \\
\text { leucas }\end{array}$ & beluga whale & XM_022583733.1 & $\begin{array}{c}\text { XP_02243944 } \\
1.1\end{array}$ \\
\hline 111554690 & BDNF & $\begin{array}{c}\text { brain derived } \\
\text { neurotrophic factor }\end{array}$ & $\begin{array}{l}\text { Piliocolobus } \\
\text { tephrosceles }\end{array}$ & $\begin{array}{l}\text { Ugandan red } \\
\text { Colobus }\end{array}$ & XM_023230347.2 & $\begin{array}{c}X P \_02308611 \\
5.1\end{array}$ \\
\hline
\end{tabular}


bioRxiv preprint doi: https://doi.org/10.1101/2022.01.21.477254; this version posted January 21, 2022. The copyright holder for this preprint (which was not certified by peer review) is the author/funder, who has granted bioRxiv a license to display the preprint in perpetuity. It is made available under aCC-BY-NC-ND 4.0 International license.

\begin{tabular}{|c|c|c|c|c|c|c|}
\hline 112303343 & BDNF & $\begin{array}{c}\text { brain derived } \\
\text { neurotrophic factor }\end{array}$ & $\begin{array}{l}\text { Desmodus } \\
\text { rotundus }\end{array}$ & $\begin{array}{l}\text { common } \\
\text { vampire bat }\end{array}$ & XM_024558903.1 & $\begin{array}{c}X P \_02441467 \\
1.1\end{array}$ \\
\hline 112412908 & BDNF & $\begin{array}{c}\text { brain derived } \\
\text { neurotrophic factor }\end{array}$ & $\begin{array}{l}\text { Neophocaena } \\
\text { asiaeorientalis } \\
\text { asiaeorientalis }\end{array}$ & $\begin{array}{l}\text { Yangtze } \\
\text { finless } \\
\text { porpoise }\end{array}$ & XM_024764694.1 & $\begin{array}{c}X P \_02462046 \\
2.1\end{array}$ \\
\hline 112607193 & BDNF & $\begin{array}{c}\text { brain derived } \\
\text { neurotrophic factor }\end{array}$ & $\begin{array}{l}\text { Theropithecus } \\
\text { gelada }\end{array}$ & gelada & XM_025358305.1 & $\begin{array}{c}\text { XP_02521409 } \\
0.1\end{array}$ \\
\hline 112667789 & BDNF & $\begin{array}{c}\text { brain derived } \\
\text { neurotrophic factor }\end{array}$ & $\begin{array}{l}\text { Canis lupus } \\
\text { dingo }\end{array}$ & dingo & XM_025459816.2 & $\begin{array}{c}X P \_02531560 \\
1.1\end{array}$ \\
\hline 112829628 & BDNF & $\begin{array}{c}\text { brain derived } \\
\text { neurotrophic factor }\end{array}$ & $\begin{array}{l}\text { Callorhinus } \\
\text { ursinus }\end{array}$ & $\begin{array}{l}\text { northern fur } \\
\text { seal }\end{array}$ & XM_025879326.1 & $\begin{array}{c}\text { XP_02573511 } \\
1.1\end{array}$ \\
\hline 112865997 & BDNF & $\begin{array}{c}\text { brain derived } \\
\text { neurotrophic factor }\end{array}$ & Puma concolor & puma & XM_025929035.1 & $\begin{array}{c}\text { XP_02578482 } \\
0.1\end{array}$ \\
\hline 112935019 & BDNF & $\begin{array}{c}\text { brain derived } \\
\text { neurotrophic factor }\end{array}$ & Vulpes vulpes & red fox & XM_026018600.1 & $\begin{array}{c}X P \_02587438 \\
5.1\end{array}$ \\
\hline 113199355 & Bdnf & $\begin{array}{c}\text { brain derived } \\
\text { neurotrophic factor }\end{array}$ & $\begin{array}{l}\text { Urocitellus } \\
\text { parryii }\end{array}$ & $\begin{array}{l}\text { Arctic ground } \\
\text { squirrel }\end{array}$ & XM_026412272.1 & $\begin{array}{c}X P \_02626805 \\
7.1\end{array}$ \\
\hline 113265088 & BDNF & $\begin{array}{c}\text { brain derived } \\
\text { neurotrophic factor }\end{array}$ & $\begin{array}{l}\text { Ursus arctos } \\
\text { horribilis }\end{array}$ & & XM_026512203.1 & $\begin{array}{c}\text { XP_02636798 } \\
8.1\end{array}$ \\
\hline 113624889 & BDNF & $\begin{array}{c}\text { brain derived } \\
\text { neurotrophic factor }\end{array}$ & $\begin{array}{l}\text { Lagenorhynchus } \\
\text { obliquidens }\end{array}$ & $\begin{array}{l}\text { Pacific white- } \\
\text { sided dolphin }\end{array}$ & XM_027115138.1 & $\begin{array}{c}X P \_02697093 \\
9.1\end{array}$ \\
\hline 113905455 & BDNF & $\begin{array}{c}\text { brain derived } \\
\text { neurotrophic factor }\end{array}$ & $\begin{array}{l}\text { Bos indicus } x \\
\text { Bos taurus }\end{array}$ & hybrid cattle & XM_027562786.1 & $\begin{array}{c}\text { XP_02741858 } \\
7.1\end{array}$ \\
\hline 113913517 & BDNF & $\begin{array}{c}\text { brain derived } \\
\text { neurotrophic factor }\end{array}$ & $\begin{array}{c}\text { Zalophus } \\
\text { californianus }\end{array}$ & $\begin{array}{l}\text { California sea } \\
\text { lion }\end{array}$ & XM_027577807.1 & $\begin{array}{c}\mathrm{XP} \_02743360 \\
8.1\end{array}$ \\
\hline 114036167 & BDNF & $\begin{array}{c}\text { brain derived } \\
\text { neurotrophic factor }\end{array}$ & $\begin{array}{l}\text { Vombatus } \\
\text { ursinus }\end{array}$ & $\begin{array}{l}\text { common } \\
\text { wombat }\end{array}$ & XM_027852578.1 & $\begin{array}{c}\text { XP_02770837 } \\
9.1\end{array}$ \\
\hline 114093712 & Bdnf & $\begin{array}{c}\text { brain derived } \\
\text { neurotrophic factor }\end{array}$ & $\begin{array}{l}\text { Marmota } \\
\text { flaviventris }\end{array}$ & $\begin{array}{c}\text { yellow-bellied } \\
\text { marmot }\end{array}$ & XM_027936596.1 & $\begin{array}{c}X P \_02779239 \\
7.1\end{array}$ \\
\hline 114220007 & BDNF & $\begin{array}{c}\text { brain derived } \\
\text { neurotrophic factor }\end{array}$ & $\begin{array}{c}\text { Eumetopias } \\
\text { jubatus }\end{array}$ & $\begin{array}{l}\text { Steller sea } \\
\quad \text { lion }\end{array}$ & XM_028117708.1 & $\begin{array}{c}X P \_02797350 \\
9.1\end{array}$ \\
\hline 114500881 & BDNF & $\begin{array}{c}\text { brain derived } \\
\text { neurotrophic factor }\end{array}$ & $\begin{array}{l}\text { Phyllostomus } \\
\text { discolor }\end{array}$ & $\begin{array}{l}\text { pale spear- } \\
\text { nosed bat }\end{array}$ & XM_028517638.2 & $\begin{array}{c}\text { XP_02837343 } \\
9.1\end{array}$ \\
\hline
\end{tabular}


bioRxiv preprint doi: https://doi.org/10.1101/2022.01.21.477254; this version posted January 21, 2022. The copyright holder for this preprint (which was not certified by peer review) is the author/funder, who has granted bioRxiv a license to display the preprint in perpetuity. It is made available under aCC-BY-NC-ND 4.0 International license.

\begin{tabular}{|c|c|c|c|c|c|c|}
\hline 114620789 & Bdnf & $\begin{array}{c}\text { brain derived } \\
\text { neurotrophic factor }\end{array}$ & $\begin{array}{l}\text { Grammomys } \\
\text { surdaster }\end{array}$ & & XM_028766921.1 & $\begin{array}{c}X P \_02862275 \\
4.1\end{array}$ \\
\hline 114702098 & Bdnf & $\begin{array}{c}\text { brain derived } \\
\text { neurotrophic factor }\end{array}$ & $\begin{array}{l}\text { Peromyscus } \\
\text { leucopus }\end{array}$ & $\begin{array}{l}\text { white-footed } \\
\text { mouse }\end{array}$ & XM_037204438.1 & $\begin{array}{c}\text { XP_03706033 } \\
3.1\end{array}$ \\
\hline 114886864 & BDNF & $\begin{array}{c}\text { brain derived } \\
\text { neurotrophic factor }\end{array}$ & $\begin{array}{l}\text { Monodon } \\
\text { monoceros }\end{array}$ & narwhal & XM_029207934.1 & $\begin{array}{c}\mathrm{XP} \_02906376 \\
7.1\end{array}$ \\
\hline 115306639 & BDNF & $\begin{array}{c}\text { brain derived } \\
\text { neurotrophic factor }\end{array}$ & $\begin{array}{l}\text { Suricata } \\
\text { suricatta }\end{array}$ & meerkat & XM_029957152.1 & $\begin{array}{c}X P \_02981301 \\
2.1\end{array}$ \\
\hline 115525821 & BDNF & $\begin{array}{c}\text { brain derived } \\
\text { neurotrophic factor }\end{array}$ & Lynx canadensis & Canada lynx & XM_030333208.1 & $\begin{array}{c}X P \_03018906 \\
8.1\end{array}$ \\
\hline 115857612 & BDNF & $\begin{array}{c}\text { brain derived } \\
\text { neurotrophic factor }\end{array}$ & $\begin{array}{l}\text { Globicephala } \\
\text { melas }\end{array}$ & $\begin{array}{l}\text { long-finned } \\
\text { pilot whale }\end{array}$ & XM_030864833.1 & $\begin{array}{c}X P \_03072069 \\
3.1\end{array}$ \\
\hline 116090620 & Bdnf & $\begin{array}{c}\text { brain derived } \\
\text { neurotrophic factor }\end{array}$ & $\begin{array}{l}\text { Mastomys } \\
\text { coucha }\end{array}$ & $\begin{array}{l}\text { southern } \\
\text { multimammat } \\
\text { e mouse }\end{array}$ & XM_031371313.1 & $\begin{array}{c}X P \_03122717 \\
3.1\end{array}$ \\
\hline 116476405 & BDNF & $\begin{array}{c}\text { brain derived } \\
\text { neurotrophic factor }\end{array}$ & $\begin{array}{l}\text { Hylobates } \\
\text { moloch }\end{array}$ & silvery gibbon & XM_032166370.1 & $\begin{array}{c}\text { XP_03202226 } \\
1.1\end{array}$ \\
\hline 116555191 & BDNF & $\begin{array}{c}\text { brain derived } \\
\text { neurotrophic factor }\end{array}$ & Sapajus apella & $\begin{array}{c}\text { tufted } \\
\text { capuchin }\end{array}$ & XM_032283691.1 & $\begin{array}{c}X P \_03213958 \\
2.1\end{array}$ \\
\hline 116599082 & BDNF & $\begin{array}{c}\text { brain derived } \\
\text { neurotrophic factor }\end{array}$ & Mustela erminea & ermine & XM_032358760.1 & $\begin{array}{c}\mathrm{XP} \_03221465 \\
1.1\end{array}$ \\
\hline 116638304 & BDNF & $\begin{array}{c}\text { brain derived } \\
\text { neurotrophic factor }\end{array}$ & Phoca vitulina & harbor seal & XM_032414183.1 & $\begin{array}{c}X P \_03227007 \\
4.1\end{array}$ \\
\hline 116758559 & BDNF & $\begin{array}{c}\text { brain derived } \\
\text { neurotrophic factor }\end{array}$ & Phocoena sinus & vaquita & XM_032641481.1 & $\begin{array}{c}X P \_03249737 \\
2.1\end{array}$ \\
\hline 116881443 & BDNF & $\begin{array}{c}\text { brain derived } \\
\text { neurotrophic factor }\end{array}$ & $\begin{array}{c}\text { Lontra } \\
\text { canadensis }\end{array}$ & $\begin{array}{c}\text { Northern } \\
\text { American river } \\
\text { otter }\end{array}$ & XM_032881246.1 & $\begin{array}{c}X P \_03273713 \\
7.1\end{array}$ \\
\hline 116901726 & Bdnf & $\begin{array}{c}\text { brain derived } \\
\text { neurotrophic factor }\end{array}$ & Rattus rattus & black rat & XM_032903861.1 & $\begin{array}{c}\text { XP_03275975 } \\
2.1\end{array}$ \\
\hline 117029758 & BDNF & $\begin{array}{c}\text { brain derived } \\
\text { neurotrophic factor }\end{array}$ & $\begin{array}{l}\text { Rhinolophus } \\
\text { ferrumequinum }\end{array}$ & $\begin{array}{c}\text { greater } \\
\text { horseshoe bat }\end{array}$ & XM_033118944.1 & $\begin{array}{c}\text { XP_03297483 } \\
5.1\end{array}$ \\
\hline 117080419 & BDNF & $\begin{array}{c}\text { brain derived } \\
\text { neurotrophic factor }\end{array}$ & $\begin{array}{l}\text { Trachypithecus } \\
\text { francoisi }\end{array}$ & $\begin{array}{l}\text { Francois's } \\
\text { langur }\end{array}$ & XM_033205475.1 & $\begin{array}{c}X P \_03306136 \\
6.1\end{array}$ \\
\hline
\end{tabular}


bioRxiv preprint doi: https://doi.org/10.1101/2022.01.21.477254; this version posted January 21, 2022. The copyright holder for this preprint (which was not certified by peer review) is the author/funder, who has granted bioRxiv a license to display the preprint in perpetuity. It is made available under aCC-BY-NC-ND 4.0 International license.

\begin{tabular}{|c|c|c|c|c|c|c|}
\hline 117704234 & Bdnf & $\begin{array}{c}\text { brain derived } \\
\text { neurotrophic factor }\end{array}$ & $\begin{array}{l}\text { Arvicanthis } \\
\text { niloticus }\end{array}$ & $\begin{array}{c}\text { African grass } \\
\text { rat }\end{array}$ & XM_034496309.1 & $\begin{array}{c}X P \_03435220 \\
0.1\end{array}$ \\
\hline 118015716 & BDNF & $\begin{array}{c}\text { brain derived } \\
\text { neurotrophic factor }\end{array}$ & $\begin{array}{l}\text { Mirounga } \\
\text { leonina }\end{array}$ & $\begin{array}{c}\text { Southern } \\
\text { elephant seal }\end{array}$ & XM_035012477.1 & $\begin{array}{c}X P \_03486836 \\
8.1\end{array}$ \\
\hline 118546649 & BDNF & $\begin{array}{c}\text { brain derived } \\
\text { neurotrophic factor }\end{array}$ & $\begin{array}{l}\text { Halichoerus } \\
\text { grypus }\end{array}$ & gray seal & XM_036109493.1 & $\begin{array}{c}X P \_03596538 \\
6.1\end{array}$ \\
\hline 118582264 & Bdnf & $\begin{array}{c}\text { brain derived } \\
\text { neurotrophic factor }\end{array}$ & $\begin{array}{l}\text { Onychomys } \\
\text { torridus }\end{array}$ & $\begin{array}{l}\text { southern } \\
\text { grasshopper } \\
\text { mouse }\end{array}$ & XM_036184983.1 & $\begin{array}{c}X P \_03604087 \\
6.1\end{array}$ \\
\hline 118628031 & BDNF & $\begin{array}{c}\text { brain derived } \\
\text { neurotrophic factor }\end{array}$ & $\begin{array}{l}\text { Molossus } \\
\text { molossus }\end{array}$ & $\begin{array}{l}\text { Pallas's } \\
\text { mastiff bat }\end{array}$ & XM_036258707.1 & $\begin{array}{c}X P \_03611460 \\
0.1\end{array}$ \\
\hline 118664943 & BDNF & $\begin{array}{c}\text { brain derived } \\
\text { neurotrophic factor }\end{array}$ & Myotis myotis & & XM_036325692.1 & $\begin{array}{c}\text { XP_03618158 } \\
5.1\end{array}$ \\
\hline 118713266 & BDNF & $\begin{array}{c}\text { brain derived } \\
\text { neurotrophic factor }\end{array}$ & Pipistrellus kuhlii & $\begin{array}{c}\text { Kuhl's } \\
\text { pipistrelle }\end{array}$ & XM_036427676.1 & $\begin{array}{c}X P \_03628356 \\
9.1\end{array}$ \\
\hline 118853508 & BDNF & $\begin{array}{c}\text { brain derived } \\
\text { neurotrophic factor }\end{array}$ & $\begin{array}{l}\text { Trichosurus } \\
\text { vulpecula }\end{array}$ & $\begin{array}{l}\text { common } \\
\text { brushtail }\end{array}$ & XM_036763631.1 & $\begin{array}{c}\text { XP_03661952 } \\
6.1\end{array}$ \\
\hline 118900201 & BDNF & $\begin{array}{c}\text { brain derived } \\
\text { neurotrophic factor }\end{array}$ & $\begin{array}{l}\text { Balaenoptera } \\
\text { musculus }\end{array}$ & Blue whale & XM_036862552.1 & $\begin{array}{c}X P \_03671844 \\
7.1\end{array}$ \\
\hline 118909009 & BDNF & $\begin{array}{c}\text { brain derived } \\
\text { neurotrophic factor }\end{array}$ & $\begin{array}{c}\text { Manis } \\
\text { pentadactyla }\end{array}$ & $\begin{array}{l}\text { Chinese } \\
\text { pangolin }\end{array}$ & XM_036879079.1 & $\begin{array}{c}X P \_03673497 \\
4.1\end{array}$ \\
\hline 118983123 & BDNF & $\begin{array}{c}\text { brain derived } \\
\text { neurotrophic factor }\end{array}$ & $\begin{array}{c}\text { Sturnira } \\
\text { hondurensis }\end{array}$ & & XM_037040421.1 & $\begin{array}{c}\text { XP_03689631 } \\
6.1\end{array}$ \\
\hline 119049902 & BDNF & $\begin{array}{c}\text { brain derived } \\
\text { neurotrophic factor }\end{array}$ & $\begin{array}{c}\text { Artibeus } \\
\text { jamaicensis }\end{array}$ & $\begin{array}{c}\text { Jamaican } \\
\text { fruit-eating bat }\end{array}$ & XM_037146035.1 & $\begin{array}{c}\text { XP_03700193 } \\
0.1\end{array}$ \\
\hline 119255407 & BDNF & $\begin{array}{c}\text { brain derived } \\
\text { neurotrophic factor }\end{array}$ & $\begin{array}{c}\text { Talpa } \\
\text { occidentalis }\end{array}$ & Iberian mole & XM_037522538.1 & $\begin{array}{c}\text { XP_03737843 } \\
5.1\end{array}$ \\
\hline 119536361 & BDNF & $\begin{array}{c}\text { brain derived } \\
\text { neurotrophic factor }\end{array}$ & $\begin{array}{l}\text { Choloepus } \\
\text { didactylus }\end{array}$ & $\begin{array}{l}\text { southern two- } \\
\text { toed sloth }\end{array}$ & XM_037839114.1 & $\begin{array}{c}\text { XP_03769504 } \\
2.1\end{array}$ \\
\hline 119815449 & Bdnf & $\begin{array}{c}\text { brain derived } \\
\text { neurotrophic factor }\end{array}$ & $\begin{array}{c}\text { Arvicola } \\
\text { amphibius }\end{array}$ & $\begin{array}{l}\text { Eurasian } \\
\text { water vole }\end{array}$ & XM_038331579.1 & $\begin{array}{c}X P \_03818750 \\
7.1\end{array}$ \\
\hline 119943514 & BDNF & $\begin{array}{c}\text { brain derived } \\
\text { neurotrophic factor }\end{array}$ & $\begin{array}{c}\text { Tachyglossus } \\
\text { aculeatus }\end{array}$ & $\begin{array}{l}\text { Australian } \\
\text { echidna }\end{array}$ & XM_038764545.1 & $\begin{array}{c}X P \_03862047 \\
3.1\end{array}$ \\
\hline 120220096 & BDNF & $\begin{array}{c}\text { brain derived } \\
\text { neurotrophic factor }\end{array}$ & Hyaena hyaena & striped hyena & XM_039217098.1 & $\begin{array}{c}X P \_03907302 \\
9.1\end{array}$ \\
\hline
\end{tabular}




\begin{tabular}{|c|c|c|c|c|c|c|}
\hline 120605221 & BDNF & $\begin{array}{c}\text { brain derived } \\
\text { neurotrophic factor }\end{array}$ & $\begin{array}{c}\text { Pteropus } \\
\text { giganteus }\end{array}$ & $\begin{array}{c}\text { Indian flying } \\
\text { fox }\end{array}$ & XM_039866065.1 & $\begin{array}{c}\text { XP_03972199 } \\
9.1\end{array}$ \\
\hline 120876831 & BDNF & $\begin{array}{c}\text { brain derived } \\
\text { neurotrophic factor }\end{array}$ & Oryx dammah & $\begin{array}{c}\text { scimitar- } \\
\text { horned oryx }\end{array}$ & XM_040258919.1 & $\begin{array}{c}\text { XP_04011485 } \\
3.1\end{array}$ \\
\hline 121043625 & BDNF & $\begin{array}{c}\text { brain derived } \\
\text { neurotrophic factor }\end{array}$ & $\begin{array}{c}\text { Pagouaroundi } \\
\text { youma }\end{array}$ & jaguarundi & XM_040495572.1 & $\begin{array}{c}\text { XP_04035150 } \\
6.1\end{array}$ \\
\hline 121156520 & BDNF & $\begin{array}{c}\text { brain derived } \\
\text { neurotrophic factor }\end{array}$ & $\begin{array}{c}\text { Ochotona } \\
\text { curzoniae }\end{array}$ & $\begin{array}{c}\text { black-lipped } \\
\text { pika }\end{array}$ & XM_040980297.1 & XP_04083623 \\
\hline 121465693 & Bdnf & $\begin{array}{c}\text { brain derived } \\
\text { neurotrophic factor }\end{array}$ & Microtus oregoni & creeping vole & XM_041679035.1 & XP_04153496 \\
\hline 121476611 & BDNF & $\begin{array}{c}\text { Xrain derived } \\
\text { neurotrophic factor }\end{array}$ & Vulpes lagopus & Arctic fox & XM_041730708.1 & XP_04158664 \\
\hline
\end{tabular}

Table 2. MEME analysis of the BDNF gene found 6 of $261(2.3 \%)$ of sites to be statistically significant (LRT $p$-value $<=0.1$ ).

\begin{tabular}{|c|c|c|c|c|c|c|c|c|c|c|c|c|c|}
\hline \# & $\frac{\text { Codon }}{\text { Site }}$ & $\begin{array}{l}\frac{\text { Huma }}{\mathrm{n}} \\
\frac{\underline{\text { Codo }}}{\mathrm{nSite}} \\
\underline{\underline{n}}\end{array}$ & alpha & beta- & p- & beta+ & $\mathrm{p}+$ & LRT & p-value & $\begin{array}{c}\frac{\text { \# branches }}{\text { under }} \\
\text { selection }\end{array}$ & $\frac{\text { MEME }}{\underline{\text { LogL }}}$ & $\underline{\text { FEL }}$ & Omega \\
\hline 1 & 26 & 26 & 0.14 & 0.00 & 0.02 & 1.12 & 0.98 & 6.89 & 0.01 & 9 & -86.53 & -86.53 & 7.9 \\
\hline 2 & 27 & 27 & 0.25 & 0.08 & 0.99 & 28.91 & 0.01 & 4.30 & 0.05 & 1 & -39.25 & -37.01 & 117.6 \\
\hline 3 & 30 & 29 & 0.00 & 0.00 & 0.00 & 0.38 & 1.00 & 4.63 & 0.05 & 6 & -35.88 & -35.88 & $\inf$ \\
\hline 4 & 38 & 36 & 0.72 & 0.00 & 0.93 & 8.07 & 0.07 & 3.80 & 0.07 & 5 & -69.22 & -66.28 & 11.3 \\
\hline 5 & 249 & 238 & 0.92 & 0.00 & 0.99 & 203.11 & 0.01 & 8.25 & 0.01 & 1 & -50.74 & -44.13 & 221.6 \\
\hline 6 & 254 & 240 & 0.23 & 0.00 & 0.99 & 1357.12 & 0.01 & 21.81 & 0.00 & 1 & -44.50 & -31.95 & 5850.4 \\
\hline
\end{tabular}

Table 3. The BGM analysis of BDNF found 23 pairs of coevolving sites out of 261 total sites to be statistically significant (with a posterior probability threshold 0.5 ).

\begin{tabular}{|c|c|c|c|c|c|c|c|c|}
\hline$\#$ & Site 1 & Site 2 & $\begin{array}{l}\text { P [Site 1 } \rightarrow \\
\text { Site 2] }\end{array}$ & $\begin{array}{l}\text { P [Site 2 } \rightarrow \\
\text { Site 1] }\end{array}$ & $\begin{array}{l}\text { P [Site 1 } \\
\text { Site 2] }\end{array}$ & $\begin{array}{l}\text { Site 1 } \\
\text { subs }\end{array}$ & $\begin{array}{l}\text { Site 2 } \\
\text { subs }\end{array}$ & $\begin{array}{l}\text { Shared } \\
\text { subs }\end{array}$ \\
\hline 1 & 5 & 67 & 0.52 & 0.32 & 0.84 & 1 & 1 & 1 \\
\hline
\end{tabular}


bioRxiv preprint doi: https://doi.org/10.1101/2022.01.21.477254; this version posted January 21, 2022. The copyright holder for this preprint

(which was not certified by peer review) is the author/funder, who has granted bioRxiv a license to display the preprint in perpetuity. It is made available under aCC-BY-NC-ND 4.0 International license.

\begin{tabular}{|c|c|c|c|c|c|c|c|c|}
\hline 2 & 25 & 49 & 0.022 & 0.67 & 0.69 & 8 & 6 & 3 \\
\hline 3 & 27 & 109 & 0.12 & 0.45 & 0.57 & 2 & 1 & 1 \\
\hline 4 & 30 & 119 & 0.2 & 0.56 & 0.75 & 6 & 12 & 4 \\
\hline 5 & 33 & 119 & 0.12 & 0.72 & 0.84 & 3 & 12 & 3 \\
\hline 6 & 39 & 103 & 0.22 & 0.58 & 0.8 & 8 & 4 & 3 \\
\hline 7 & 49 & 85 & 0.48 & 0.049 & 0.53 & 6 & 3 & 2 \\
\hline 8 & 49 & 86 & 0.36 & 0.55 & 0.91 & 6 & 5 & 3 \\
\hline 9 & 50 & 69 & 0.31 & 0.27 & 0.58 & 1 & 2 & 1 \\
\hline 10 & 62 & 64 & 0.25 & 0.27 & 0.52 & 1 & 1 & 1 \\
\hline 11 & 70 & 74 & 0.17 & 0.38 & 0.55 & 7 & 14 & 4 \\
\hline 12 & 70 & 95 & 0.59 & 0.26 & 0.85 & 7 & 21 & 5 \\
\hline 13 & 74 & 94 & 0.034 & 0.64 & 0.68 & 14 & 7 & 4 \\
\hline 14 & 78 & 90 & 0.46 & 0.38 & 0.84 & 1 & 1 & 1 \\
\hline 15 & 81 & 93 & 0.27 & 0.31 & 0.58 & 1 & 1 & 1 \\
\hline 16 & 81 & 98 & 0.27 & 0.33 & 0.61 & 1 & 1 & 1 \\
\hline 17 & 82 & 91 & 0.045 & 0.92 & 0.96 & 15 & 29 & 9 \\
\hline 18 & 89 & 184 & 0.24 & 0.5 & 0.74 & 2 & 6 & 2 \\
\hline
\end{tabular}




\begin{tabular}{|c|c|c|c|c|c|c|c|c|}
\hline 19 & 91 & 119 & 0.22 & 0.67 & 0.89 & 29 & 12 & 8 \\
\hline 20 & 93 & 98 & 0.31 & 0.3 & 0.61 & 1 & 1 & 1 \\
\hline 21 & 94 & 155 & 0.28 & 0.29 & 0.57 & 7 & 2 & 2 \\
\hline 22 & 103 & 233 & 0.4 & 0.13 & 0.53 & 4 & 3 & 2 \\
\hline 23 & 135 & 154 & 0.4 & 0.43 & 0.82 & 1 & 1 & 1 \\
\hline
\end{tabular}

\section{Supplementary Material}

Table S1. The FEL analysis of the BDNF gene found 174 of $261(66.7 \%)$ sites to be statistically significant (LRT $p$-value $<=0.1$ ) for pervasive negative (purifying) selection.

\begin{tabular}{|c|c|c|c|c|c|c|c|c|c|}
\hline Site & alpha & beta & alpha=beta & LRT & $p$-value & $\begin{array}{c}\text { Total } \\
\text { branch } \\
\text { length }\end{array}$ & dN/dS LB & $\begin{array}{c}\mathrm{dN} / \mathrm{dS} \\
\mathrm{MLE}\end{array}$ & dN/dS UB \\
\hline 1 & 0.0000 & 0.0000 & 0.0000 & 0.0000 & 1.0000 & 0.0000 & 0.0000 & 0.0000 & 0.0000 \\
\hline 2 & 0.0000 & 0.0000 & 0.0000 & 0.0000 & 1.0000 & 0.0000 & 0.0000 & 0.0000 & 0.0000 \\
\hline 3 & 0.0000 & 0.0000 & 0.0000 & 0.0000 & 1.0000 & 0.0000 & 0.0000 & 0.0000 & 0.0000 \\
\hline 4 & 0.1116 & 0.0635 & 0.0811 & 0.1573 & 0.6916 & 0.6594 & 0.0325 & 0.5690 & 2.5205 \\
\hline 5 & 0.0000 & 0.0564 & 0.0468 & 0.3606 & 0.5482 & 0.3806 & 1462.7972 & $\begin{array}{c}10000.000 \\
0\end{array}$ & $\begin{array}{c}10000.000 \\
0\end{array}$ \\
\hline 6 & 0.2221 & 0.0000 & 0.0805 & 4.0430 & 0.0444 & 0.6545 & 0.0000 & 0.0000 & 0.5478 \\
\hline 7 & 0.0000 & 0.0000 & 0.0000 & 0.0000 & 1.0000 & 0.0000 & 0.0000 & 0.0000 & 0.0000 \\
\hline
\end{tabular}


bioRxiv preprint doi: https://doi.org/10.1101/2022.01.21.477254; this version posted January 21, 2022. The copyright holder for this preprint (which was not certified by peer review) is the author/funder, who has granted bioRxiv a license to display the preprint in perpetuity. It is made available under aCC-BY-NC-ND 4.0 International license.

\begin{tabular}{|c|c|c|c|c|c|c|c|c|c|}
\hline 8 & 0.0000 & 0.0000 & 0.0000 & 0.0000 & 1.0000 & 0.0000 & 0.0000 & 0.0000 & 0.0000 \\
\hline 9 & 0.0928 & 0.0000 & 0.0397 & 2.0198 & 0.1553 & 0.3227 & 0.0000 & 0.0000 & 1.2848 \\
\hline 10 & 0.1594 & 0.0000 & 0.0409 & 2.7359 & 0.0981 & 0.3326 & 0.0000 & 0.0000 & 0.6580 \\
\hline 11 & 0.1729 & 0.0000 & 0.0900 & 3.1185 & 0.0774 & 0.7317 & 0.0000 & 0.0000 & 0.9176 \\
\hline 12 & 0.0000 & 0.0000 & 0.0000 & 0.0000 & 1.0000 & 0.0000 & 0.0000 & 0.0000 & 0.0000 \\
\hline 13 & 1.9630 & 0.0000 & 0.2850 & 22.6368 & 0.0000 & 2.3174 & 0.0000 & 0.0000 & 0.0549 \\
\hline 14 & 0.0000 & 0.2172 & 0.1438 & 3.0861 & 0.0790 & 1.1694 & 6185.5906 & $\begin{array}{c}10000.000 \\
0\end{array}$ & $\begin{array}{c}10000.000 \\
0\end{array}$ \\
\hline 15 & 0.0000 & 0.0000 & 0.0000 & 0.0000 & 1.0000 & 0.0000 & 0.0000 & 0.0000 & 0.0000 \\
\hline 16 & 0.0000 & 0.0000 & 0.0000 & 0.0000 & 1.0000 & 0.0000 & 0.0000 & 0.0000 & 0.0000 \\
\hline 17 & 0.2673 & 0.0530 & 0.0885 & 1.1690 & 0.2796 & 0.7199 & 0.0113 & 0.1982 & 0.8804 \\
\hline 18 & 0.3413 & 0.0000 & 0.1102 & 6.7673 & 0.0093 & 0.8958 & 0.0000 & 0.0000 & 0.3054 \\
\hline 19 & 0.4344 & 0.0000 & 0.1182 & 7.7643 & 0.0053 & 0.9612 & 0.0000 & 0.0000 & 0.2399 \\
\hline 20 & 0.7437 & 0.0000 & 0.1993 & 12.7922 & 0.0003 & 1.6204 & 0.0000 & 0.0000 & 0.1425 \\
\hline 21 & 0.0000 & 0.0000 & 0.0000 & 0.0000 & 1.0000 & 0.0000 & 0.0000 & 0.0000 & 0.0000 \\
\hline 22 & 0.7734 & 0.0000 & 0.1935 & 13.6496 & 0.0002 & 1.5734 & 0.0000 & 0.0000 & 0.1283 \\
\hline 23 & 0.1435 & 0.0527 & 0.0773 & 0.4750 & 0.4907 & 0.6284 & 0.0210 & 0.3670 & 1.6325 \\
\hline 24 & 1.7963 & 0.4672 & 0.8629 & 8.8413 & 0.0029 & 7.0170 & 0.1183 & 0.2601 & 0.4893 \\
\hline
\end{tabular}


bioRxiv preprint doi: https://doi.org/10.1101/2022.01.21.477254; this version posted January 21, 2022. The copyright holder for this preprint (which was not certified by peer review) is the author/funder, who has granted bioRxiv a license to display the preprint in perpetuity. It is made available under aCC-BY-NC-ND 4.0 International license.

\begin{tabular}{|c|c|c|c|c|c|c|c|c|c|}
\hline 25 & 1.4891 & 0.3979 & 0.5537 & 4.2623 & 0.0390 & 4.5023 & 0.1213 & 0.2672 & 0.5042 \\
\hline 26 & 0.1396 & 1.0896 & 0.7817 & 6.8872 & 0.0087 & 6.3560 & 4.5038 & 7.8049 & 12.5990 \\
\hline 27 & 0.2849 & 0.2004 & 0.2436 & 0.1449 & 0.7035 & 1.9806 & 0.1198 & 0.7033 & 2.1145 \\
\hline 28 & 0.0000 & 0.0000 & 0.0000 & 0.0000 & 1.0000 & 0.0000 & 0.0000 & 0.0000 & 0.0000 \\
\hline 29 & 0.4139 & 0.0566 & 0.1834 & 4.1399 & 0.0419 & 1.4914 & 0.0078 & 0.1367 & 0.6064 \\
\hline 30 & 0.0000 & 0.3797 & 0.2579 & 4.6268 & 0.0315 & 2.0973 & 7260.0520 & $\begin{array}{c}10000.000 \\
0\end{array}$ & $\begin{array}{c}10000.000 \\
0\end{array}$ \\
\hline 31 & 0.2774 & 0.0000 & 0.0763 & 5.1487 & 0.0233 & 0.6206 & 0.0000 & 0.0000 & 0.3653 \\
\hline 32 & 0.2572 & 0.4242 & 0.3976 & 0.2465 & 0.6196 & 3.2327 & 0.7845 & 1.6493 & 3.0082 \\
\hline 33 & 0.3030 & 0.2456 & 0.2654 & 0.0484 & 0.8259 & 2.1581 & 0.2009 & 0.8105 & 2.1234 \\
\hline 34 & 1.0536 & 0.1089 & 0.3602 & 9.9540 & 0.0016 & 2.9291 & 0.0172 & 0.1034 & 0.3222 \\
\hline 35 & 0.0000 & 0.0000 & 0.0000 & 0.0000 & 1.0000 & 0.0000 & 0.0000 & 0.0000 & 0.0000 \\
\hline 36 & 0.2906 & 0.0686 & 0.1107 & 0.9484 & 0.3301 & 0.9000 & 0.0134 & 0.2360 & 1.0454 \\
\hline 37 & 0.8023 & 0.0000 & 0.2613 & 15.6626 & 0.0001 & 2.1248 & 0.0000 & 0.0000 & 0.1321 \\
\hline 38 & 0.7113 & 0.3303 & 0.4528 & 1.6696 & 0.1963 & 3.6817 & 0.1837 & 0.4644 & 0.9547 \\
\hline 39 & 0.4421 & 0.5250 & 0.5030 & 0.0485 & 0.8256 & 4.0903 & 0.5420 & 1.1877 & 2.2205 \\
\hline 40 & 0.4097 & 0.0000 & 0.1578 & 7.5858 & 0.0059 & 1.2834 & 0.0000 & 0.0000 & 0.3013 \\
\hline 41 & 0.0000 & 0.0551 & 0.0393 & 0.6774 & 0.4105 & 0.3195 & 1462.7591 & $\begin{array}{c}10000.000 \\
0\end{array}$ & $\begin{array}{c}10000.000 \\
0\end{array}$ \\
\hline
\end{tabular}


bioRxiv preprint doi: https://doi.org/10.1101/2022.01.21.477254; this version posted January 21, 2022. The copyright holder for this preprint (which was not certified by peer review) is the author/funder, who has granted bioRxiv a license to display the preprint in perpetuity. It is made available under aCC-BY-NC-ND 4.0 International license.

\begin{tabular}{|c|c|c|c|c|c|c|c|c|c|}
\hline 42 & 1.2391 & 0.0506 & 0.2862 & 13.8667 & 0.0002 & 2.3274 & 0.0023 & 0.0409 & 0.1816 \\
\hline 43 & 0.1559 & 0.0000 & 0.0396 & 2.7457 & 0.0975 & 0.3218 & 0.0000 & 0.0000 & 0.6535 \\
\hline 44 & 0.3404 & 0.0556 & 0.1494 & 2.9408 & 0.0864 & 1.2148 & 0.0093 & 0.1634 & 0.7237 \\
\hline 45 & 0.0928 & 0.0000 & 0.0443 & 1.4933 & 0.2217 & 0.3605 & 0.0000 & 0.0000 & 1.7490 \\
\hline 46 & 0.0000 & 0.1640 & 0.1370 & 1.0523 & 0.3050 & 1.1140 & 5270.0970 & $\begin{array}{c}10000.000 \\
0\end{array}$ & $\begin{array}{c}10000.000 \\
0\end{array}$ \\
\hline 47 & 1.8271 & 0.1373 & 0.3286 & 11.8421 & 0.0006 & 2.6721 & 0.0187 & 0.0751 & 0.1965 \\
\hline 48 & 0.7118 & 1.0257 & 0.9372 & 0.4209 & 0.5165 & 7.6211 & 0.8165 & 1.4411 & 2.3527 \\
\hline 49 & 1.3089 & 0.3744 & 0.5850 & 4.9417 & 0.0262 & 4.7570 & 0.1222 & 0.2860 & 0.5605 \\
\hline 50 & 0.2882 & 0.0532 & 0.1161 & 2.0383 & 0.1534 & 0.9440 & 0.0105 & 0.1844 & 0.8138 \\
\hline 51 & 0.1419 & 0.0000 & 0.0395 & 2.5243 & 0.1121 & 0.3214 & 0.0000 & 0.0000 & 0.7470 \\
\hline 52 & 0.2736 & 0.3297 & 0.3204 & 0.0312 & 0.8599 & 2.6057 & 0.4762 & 1.2050 & 2.4754 \\
\hline 53 & 1.5426 & 0.4637 & 0.8202 & 7.0701 & 0.0078 & 6.6692 & 0.1365 & 0.3006 & 0.5668 \\
\hline 54 & 1.5617 & 0.2216 & 0.6252 & 13.3081 & 0.0003 & 5.0838 & 0.0440 & 0.1419 & 0.3335 \\
\hline 55 & 3.6302 & 0.5463 & 1.6240 & 22.5001 & 0.0000 & 13.2053 & 0.0643 & 0.1505 & 0.2957 \\
\hline 56 & 1.5021 & 0.0545 & 0.4719 & 20.6584 & 0.0000 & 3.8374 & 0.0021 & 0.0363 & 0.1612 \\
\hline 57 & 0.5526 & 0.2782 & 0.3576 & 0.9810 & 0.3220 & 2.9080 & 0.1797 & 0.5034 & 1.0950 \\
\hline 58 & 0.3979 & 0.0869 & 0.2313 & 2.3382 & 0.1262 & 1.8808 & 0.0124 & 0.2184 & 0.9655 \\
\hline
\end{tabular}


bioRxiv preprint doi: https://doi.org/10.1101/2022.01.21.477254; this version posted January 21, 2022. The copyright holder for this preprint (which was not certified by peer review) is the author/funder, who has granted bioRxiv a license to display the preprint in perpetuity. It is made available under aCC-BY-NC-ND 4.0 International license.

\begin{tabular}{|c|c|c|c|c|c|c|c|c|c|}
\hline 59 & 11.1190 & 0.8319 & 1.4313 & 1.5693 & 0.2103 & 11.6383 & 0.0038 & 0.0748 & 0.6522 \\
\hline 60 & 4.3720 & 0.3686 & 1.3037 & 33.3567 & 0.0000 & 10.6014 & 0.0332 & 0.0843 & 0.1727 \\
\hline 61 & 0.0000 & 0.0000 & 0.0000 & 0.0000 & 1.0000 & 0.0000 & 0.0000 & 0.0000 & 0.0000 \\
\hline 62 & 1.7721 & $\begin{array}{c}2193.285 \\
7\end{array}$ & 2856.9387 & 0.0000 & 1.0000 & $\begin{array}{c}23231.30 \\
76\end{array}$ & 0.3292 & 1237.7020 & $\begin{array}{c}10000.000 \\
0\end{array}$ \\
\hline 63 & 0.0000 & 3.6440 & 2.0642 & 0.9793 & 0.3224 & 16.7849 & 1464.9793 & $\begin{array}{c}10000.000 \\
0\end{array}$ & $\begin{array}{c}10000.000 \\
0\end{array}$ \\
\hline 64 & 7.4868 & 0.0000 & 1.0937 & 6.3427 & 0.0118 & 8.8931 & 0.0000 & 0.0000 & 0.1725 \\
\hline 65 & 122.5088 & 0.0000 & 1.1740 & 7.2662 & 0.0070 & 9.5464 & 0.0000 & 0.0000 & 0.0108 \\
\hline 66 & 2.8095 & 0.0000 & 0.7275 & 4.7774 & 0.0288 & 5.9161 & 0.0000 & 0.0000 & 0.3619 \\
\hline 67 & 10.8121 & 0.0000 & 1.6286 & 13.5042 & 0.0002 & 13.2432 & 0.0000 & 0.0000 & 0.0777 \\
\hline 68 & 4.1586 & 0.4872 & 1.5564 & 8.0811 & 0.0045 & 12.6556 & 0.0193 & 0.1172 & 0.3731 \\
\hline 69 & 3.2764 & 0.3962 & 1.3489 & 22.0059 & 0.0000 & 10.9685 & 0.0431 & 0.1209 & 0.2630 \\
\hline 70 & 0.9289 & 0.0000 & 0.3524 & 13.2397 & 0.0003 & 2.8657 & 0.0000 & 0.0000 & 0.1693 \\
\hline 71 & 1.1053 & 0.0000 & 0.3383 & 20.8817 & 0.0000 & 2.7513 & 0.0000 & 0.0000 & 0.0943 \\
\hline 72 & 0.2921 & 0.0985 & 0.1261 & 0.6630 & 0.4155 & 1.0251 & 0.0558 & 0.3373 & 1.0461 \\
\hline 73 & 1.1053 & 0.0000 & 0.3395 & 20.5444 & 0.0000 & 2.7603 & 0.0000 & 0.0000 & 0.0954 \\
\hline 74 & 2.9165 & 0.0575 & 0.6252 & 32.3768 & 0.0000 & 5.0841 & 0.0011 & 0.0197 & 0.0877 \\
\hline 75 & 0.8228 & 0.0000 & 0.2007 & 13.9151 & 0.0002 & 1.6320 & 0.0000 & 0.0000 & 0.1241 \\
\hline
\end{tabular}


bioRxiv preprint doi: https://doi.org/10.1101/2022.01.21.477254; this version posted January 21, 2022. The copyright holder for this preprint (which was not certified by peer review) is the author/funder, who has granted bioRxiv a license to display the preprint in perpetuity. It is made available under aCC-BY-NC-ND 4.0 International license.

\begin{tabular}{|c|c|c|c|c|c|c|c|c|c|}
\hline 76 & 5.5185 & 0.0000 & 0.5700 & 53.7705 & 0.0000 & 4.6353 & 0.0000 & 0.0000 & 0.0174 \\
\hline 77 & 0.6280 & 0.0619 & 0.2215 & 5.6574 & 0.0174 & 1.8010 & 0.0056 & 0.0985 & 0.4366 \\
\hline 78 & 2.1641 & 0.0489 & 0.3787 & 23.0125 & 0.0000 & 3.0792 & 0.0013 & 0.0226 & 0.1005 \\
\hline 79 & 1.8388 & 0.0000 & 0.4162 & 29.0685 & 0.0000 & 3.3840 & 0.0000 & 0.0000 & 0.0556 \\
\hline 80 & 0.2839 & 0.0541 & 0.0909 & 1.2074 & 0.2718 & 0.7393 & 0.0109 & 0.1905 & 0.8475 \\
\hline 81 & 1.3529 & 0.0000 & 0.5463 & 20.2275 & 0.0000 & 4.4420 & 0.0000 & 0.0000 & 0.1126 \\
\hline 82 & 1.8857 & 0.0830 & 0.7606 & 19.4503 & 0.0000 & 6.1851 & 0.0025 & 0.0440 & 0.1950 \\
\hline 83 & 2.4273 & 0.1547 & 0.5523 & 20.6750 & 0.0000 & 4.4910 & 0.0157 & 0.0637 & 0.1663 \\
\hline 84 & 0.5934 & 0.0000 & 0.0911 & 7.3673 & 0.0066 & 0.7411 & 0.0000 & 0.0000 & 0.1756 \\
\hline 85 & 0.3406 & 0.1489 & 0.1729 & 0.4375 & 0.5083 & 1.4059 & 0.1081 & 0.4371 & 1.1399 \\
\hline 86 & 0.0000 & 0.3235 & 0.2567 & 2.3672 & 0.1239 & 2.0875 & 6809.7393 & $\begin{array}{c}10000.000 \\
0\end{array}$ & $\begin{array}{c}10000.000 \\
0\end{array}$ \\
\hline 87 & 1.2767 & 0.1562 & 0.4047 & 9.9233 & 0.0016 & 3.2907 & 0.0303 & 0.1223 & 0.3201 \\
\hline 88 & 1.3410 & 0.5707 & 0.8242 & 3.2658 & 0.0707 & 6.7019 & 0.2024 & 0.4256 & 0.7810 \\
\hline 89 & 1.2511 & 0.1289 & 0.5092 & 12.0135 & 0.0005 & 4.1408 & 0.0170 & 0.1031 & 0.3194 \\
\hline 90 & 0.6067 & 0.0552 & 0.2020 & 6.0849 & 0.0136 & 1.6429 & 0.0052 & 0.0910 & 0.4030 \\
\hline 91 & 4.6374 & 1.7289 & 2.1855 & 6.6899 & 0.0097 & 17.7717 & 0.2477 & 0.3728 & 0.5401 \\
\hline 92 & 1.8962 & 0.0535 & 0.4607 & 23.2267 & 0.0000 & 3.7463 & 0.0016 & 0.0282 & 0.1245 \\
\hline
\end{tabular}


bioRxiv preprint doi: https://doi.org/10.1101/2022.01.21.477254; this version posted January 21, 2022. The copyright holder for this preprint (which was not certified by peer review) is the author/funder, who has granted bioRxiv a license to display the preprint in perpetuity. It is made available under aCC-BY-NC-ND 4.0 International license.

\begin{tabular}{|c|c|c|c|c|c|c|c|c|c|}
\hline 93 & 3.5662 & 0.0542 & 0.7407 & 40.9892 & 0.0000 & 6.0226 & 0.0009 & 0.0152 & 0.0676 \\
\hline 94 & 1.3252 & 0.3547 & 0.4855 & 3.6636 & 0.0556 & 3.9476 & 0.1139 & 0.2676 & 0.5226 \\
\hline 95 & 1.3323 & 1.5991 & 1.5317 & 0.1473 & 0.7011 & 12.4555 & 0.7548 & 1.2003 & 1.8159 \\
\hline 96 & 1.3529 & 0.0000 & 0.1787 & 14.6186 & 0.0001 & 1.4535 & 0.0000 & 0.0000 & 0.0749 \\
\hline 97 & 1.8434 & 0.0489 & 0.2953 & 17.5494 & 0.0000 & 2.4011 & 0.0015 & 0.0265 & 0.1178 \\
\hline 98 & 0.6510 & 0.0536 & 0.2046 & 6.5994 & 0.0102 & 1.6636 & 0.0047 & 0.0824 & 0.3692 \\
\hline 99 & 0.0000 & 0.0000 & 0.0000 & 0.0000 & 1.0000 & 0.0000 & 0.0000 & 0.0000 & 0.0000 \\
\hline 100 & 0.5931 & 0.3419 & 0.4207 & 0.4996 & 0.4797 & 3.4205 & 0.1807 & 0.5764 & 1.3251 \\
\hline 101 & 5.6241 & 0.0678 & 0.7121 & 36.3681 & 0.0000 & 5.7902 & 0.0007 & 0.0120 & 0.0536 \\
\hline 102 & 2.4986 & 0.1708 & 0.7664 & 25.4012 & 0.0000 & 6.2322 & 0.0169 & 0.0684 & 0.1784 \\
\hline 103 & 0.6960 & 0.0000 & 0.2116 & 11.7725 & 0.0006 & 1.7204 & 0.0000 & 0.0000 & 0.1687 \\
\hline 104 & 2.3048 & 0.0000 & 0.5043 & 34.9881 & 0.0000 & 4.1010 & 0.0000 & 0.0000 & 0.0444 \\
\hline 105 & 0.6641 & 0.0000 & 0.1786 & 10.1702 & 0.0014 & 1.4520 & 0.0000 & 0.0000 & 0.1795 \\
\hline 106 & 0.0000 & 0.0000 & 0.0000 & 0.0000 & 1.0000 & 0.0000 & 0.0000 & 0.0000 & 0.0000 \\
\hline 107 & 0.9618 & 0.0000 & 0.3094 & 15.6026 & 0.0001 & 2.5158 & 0.0000 & 0.0000 & 0.1311 \\
\hline 108 & 1.7507 & 0.0000 & 0.2683 & 25.8194 & 0.0000 & 2.1813 & 0.0000 & 0.0000 & 0.0495 \\
\hline 109 & 1.2561 & 0.0472 & 0.2636 & 13.7621 & 0.0002 & 2.1434 & 0.0021 & 0.0376 & 0.1661 \\
\hline
\end{tabular}


bioRxiv preprint doi: https://doi.org/10.1101/2022.01.21.477254; this version posted January 21, 2022. The copyright holder for this preprint (which was not certified by peer review) is the author/funder, who has granted bioRxiv a license to display the preprint in perpetuity. It is made available under aCC-BY-NC-ND 4.0 International license.

\begin{tabular}{|c|c|c|c|c|c|c|c|c|c|}
\hline 110 & 0.3333 & 0.0000 & 0.0900 & 5.1186 & 0.0237 & 0.7317 & 0.0000 & 0.0000 & 0.3586 \\
\hline 111 & 0.0000 & 0.0000 & 0.0000 & 0.0000 & 1.0000 & 0.0000 & 0.0000 & 0.0000 & 0.0000 \\
\hline 112 & 0.2221 & 0.0000 & 0.0736 & 4.3993 & 0.0360 & 0.5984 & 0.0000 & 0.0000 & 0.4774 \\
\hline 113 & 0.2700 & 0.0000 & 0.1012 & 3.9075 & 0.0481 & 0.8232 & 0.0000 & 0.0000 & 0.5785 \\
\hline 114 & 0.6015 & 0.0000 & 0.0925 & 7.5591 & 0.0060 & 0.7518 & 0.0000 & 0.0000 & 0.1729 \\
\hline 115 & 2.1843 & 0.0000 & 0.5950 & 37.4897 & 0.0000 & 4.8380 & 0.0000 & 0.0000 & 0.0485 \\
\hline 116 & 1.7115 & 0.0000 & 0.4751 & 29.9207 & 0.0000 & 3.8634 & 0.0000 & 0.0000 & 0.0619 \\
\hline 117 & 1.3529 & 0.0000 & 0.4841 & 22.7688 & 0.0000 & 3.9361 & 0.0000 & 0.0000 & 0.0965 \\
\hline 118 & 0.2799 & 0.0000 & 0.0871 & 4.6517 & 0.0310 & 0.7081 & 0.0000 & 0.0000 & 0.4354 \\
\hline 119 & 2.6166 & 0.0000 & 0.5451 & 36.1605 & 0.0000 & 4.4325 & 0.0000 & 0.0000 & 0.0423 \\
\hline 120 & 0.0928 & 0.0000 & 0.0445 & 1.5555 & 0.2123 & 0.3619 & 0.0000 & 0.0000 & 1.7079 \\
\hline 121 & 3.0538 & 0.0000 & 0.9175 & 44.7049 & 0.0000 & 7.4605 & 0.0000 & 0.0000 & 0.0424 \\
\hline 122 & 0.0000 & 0.0000 & 0.0000 & 0.0000 & 1.0000 & 0.0000 & 0.0000 & 0.0000 & 0.0000 \\
\hline 123 & 0.5018 & 0.0000 & 0.1210 & 8.4758 & 0.0036 & 0.9840 & 0.0000 & 0.0000 & 0.2034 \\
\hline 124 & 0.0000 & 0.0000 & 0.0000 & 0.0000 & 1.0000 & 0.0000 & 0.0000 & 0.0000 & 0.0000 \\
\hline 125 & 0.0000 & 0.0000 & 0.0000 & 0.0000 & 1.0000 & 0.0000 & 0.0000 & 0.0000 & 0.0000 \\
\hline 126 & 0.1674 & 0.0519 & 0.0785 & 0.6645 & 0.4150 & 0.6381 & 0.0174 & 0.3101 & 1.3547 \\
\hline
\end{tabular}


bioRxiv preprint doi: https://doi.org/10.1101/2022.01.21.477254; this version posted January 21, 2022. The copyright holder for this preprint (which was not certified by peer review) is the author/funder, who has granted bioRxiv a license to display the preprint in perpetuity. It is made available under aCC-BY-NC-ND 4.0 International license.

\begin{tabular}{|c|c|c|c|c|c|c|c|c|c|}
\hline 127 & 0.5910 & 0.0680 & 0.1651 & 3.2197 & 0.0728 & 1.3427 & 0.0066 & 0.1151 & 0.5099 \\
\hline 128 & 0.4829 & 0.0000 & 0.2240 & 7.5898 & 0.0059 & 1.8217 & 0.0000 & 0.0000 & 0.3344 \\
\hline 129 & 0.7281 & 0.0000 & 0.1574 & 12.1458 & 0.0005 & 1.2801 & 0.0000 & 0.0000 & 0.1324 \\
\hline 130 & 1.3529 & 0.0000 & 0.4223 & 26.4290 & 0.0000 & 3.4343 & 0.0000 & 0.0000 & 0.0770 \\
\hline 131 & 1.3529 & 0.0000 & 0.4072 & 24.6703 & 0.0000 & 3.3113 & 0.0000 & 0.0000 & 0.0770 \\
\hline 132 & 0.5994 & 0.0000 & 0.0843 & 7.7423 & 0.0054 & 0.6853 & 0.0000 & 0.0000 & 0.1579 \\
\hline 133 & 0.0000 & 0.0000 & 0.0000 & 0.0000 & 1.0000 & 0.0000 & 0.0000 & 0.0000 & 0.0000 \\
\hline 134 & 2.4575 & 0.0000 & 0.6712 & 37.7462 & 0.0000 & 5.4579 & 0.0000 & 0.0000 & 0.0483 \\
\hline 135 & 0.0000 & 0.0435 & 0.0438 & 0.0008 & 0.9774 & 0.3558 & 1462.1672 & $\begin{array}{c}10000.000 \\
0\end{array}$ & $\begin{array}{c}10000.000 \\
0\end{array}$ \\
\hline 136 & 1.0696 & 0.0000 & 0.2395 & 17.4870 & 0.0000 & 1.9473 & 0.0000 & 0.0000 & 0.0925 \\
\hline 137 & 0.4335 & 0.0000 & 0.1301 & 7.1875 & 0.0073 & 1.0578 & 0.0000 & 0.0000 & 0.2750 \\
\hline 138 & 0.6509 & 0.0000 & 0.2392 & 11.8685 & 0.0006 & 1.9451 & 0.0000 & 0.0000 & 0.1867 \\
\hline 139 & 0.4217 & 0.0000 & 0.1161 & 7.6814 & 0.0056 & 0.9442 & 0.0000 & 0.0000 & 0.2443 \\
\hline 140 & 0.9836 & 0.0000 & 0.1277 & 11.8927 & 0.0006 & 1.0384 & 0.0000 & 0.0000 & 0.0967 \\
\hline 141 & 3.5104 & 0.0000 & 0.9082 & 50.5522 & 0.0000 & 7.3849 & 0.0000 & 0.0000 & 0.0344 \\
\hline 142 & 0.0000 & 0.0000 & 0.0000 & 0.0000 & 1.0000 & 0.0000 & 0.0000 & 0.0000 & 0.0000 \\
\hline 143 & 3.8890 & 0.0000 & 0.8487 & 57.0286 & 0.0000 & 6.9012 & 0.0000 & 0.0000 & 0.0273 \\
\hline
\end{tabular}


bioRxiv preprint doi: https://doi.org/10.1101/2022.01.21.477254; this version posted January 21, 2022. The copyright holder for this preprint (which was not certified by peer review) is the author/funder, who has granted bioRxiv a license to display the preprint in perpetuity. It is made available under aCC-BY-NC-ND 4.0 International license.

\begin{tabular}{|c|c|c|c|c|c|c|c|c|c|}
\hline 144 & 0.5803 & 0.0000 & 0.1576 & 10.3294 & 0.0013 & 1.2818 & 0.0000 & 0.0000 & 0.1796 \\
\hline 145 & 0.8551 & 0.0000 & 0.2336 & 15.3582 & 0.0001 & 1.8993 & 0.0000 & 0.0000 & 0.1209 \\
\hline 146 & 3.1941 & 0.0000 & 0.8296 & 52.1403 & 0.0000 & 6.7458 & 0.0000 & 0.0000 & 0.0335 \\
\hline 147 & 0.4576 & 0.0000 & 0.1172 & 8.0791 & 0.0045 & 0.9527 & 0.0000 & 0.0000 & 0.2215 \\
\hline 148 & 0.0000 & 0.0000 & 0.0000 & 0.0000 & 1.0000 & 0.0000 & 0.0000 & 0.0000 & 0.0000 \\
\hline 149 & 0.1879 & 0.0000 & 0.0883 & 2.9817 & 0.0842 & 0.7177 & 0.0000 & 0.0000 & 0.8603 \\
\hline 150 & 2.4574 & 0.0000 & 0.2729 & 29.1158 & 0.0000 & 2.2192 & 0.0000 & 0.0000 & 0.0347 \\
\hline 151 & 1.3529 & 0.0000 & 0.3641 & 20.8617 & 0.0000 & 2.9610 & 0.0000 & 0.0000 & 0.0881 \\
\hline 152 & 1.8431 & 0.0000 & 0.3369 & 26.2702 & 0.0000 & 2.7398 & 0.0000 & 0.0000 & 0.0543 \\
\hline 153 & 0.0000 & 0.0000 & 0.0000 & 0.0000 & 1.0000 & 0.0000 & 0.0000 & 0.0000 & 0.0000 \\
\hline 154 & 1.1326 & 0.0449 & 0.2254 & 12.6183 & 0.0004 & 1.8326 & 0.0023 & 0.0397 & 0.1759 \\
\hline 155 & 1.9612 & 0.1105 & 0.5215 & 19.7057 & 0.0000 & 4.2410 & 0.0093 & 0.0564 & 0.1754 \\
\hline 156 & 9.5442 & 0.0000 & 0.6185 & 72.6680 & 0.0000 & 5.0296 & 0.0000 & 0.0000 & 0.0090 \\
\hline 157 & 0.5748 & 0.0547 & 0.1375 & 3.7909 & 0.0515 & 1.1182 & 0.0054 & 0.0951 & 0.4215 \\
\hline 158 & 0.0000 & 0.0000 & 0.0000 & 0.0000 & 1.0000 & 0.0000 & 0.0000 & 0.0000 & 0.0000 \\
\hline 159 & 2.8095 & 0.0000 & 0.8095 & 44.3396 & 0.0000 & 6.5824 & 0.0000 & 0.0000 & 0.0424 \\
\hline 160 & 2.4575 & 0.0000 & 0.6733 & 41.9754 & 0.0000 & 5.4754 & 0.0000 & 0.0000 & 0.0429 \\
\hline
\end{tabular}


bioRxiv preprint doi: https://doi.org/10.1101/2022.01.21.477254; this version posted January 21, 2022. The copyright holder for this preprint (which was not certified by peer review) is the author/funder, who has granted bioRxiv a license to display the preprint in perpetuity. It is made available under aCC-BY-NC-ND 4.0 International license.

\begin{tabular}{|c|c|c|c|c|c|c|c|c|c|}
\hline 161 & 3.1758 & 0.0000 & 0.7134 & 48.2008 & 0.0000 & 5.8007 & 0.0000 & 0.0000 & 0.0328 \\
\hline 162 & 1.3529 & 0.0000 & 0.3849 & 24.2341 & 0.0000 & 3.1298 & 0.0000 & 0.0000 & 0.0770 \\
\hline 163 & 1.6026 & 0.0501 & 0.3633 & 19.2676 & 0.0000 & 2.9542 & 0.0018 & 0.0313 & 0.1388 \\
\hline 164 & 0.6094 & 0.0000 & 0.1545 & 10.8904 & 0.0010 & 1.2565 & 0.0000 & 0.0000 & 0.1629 \\
\hline 165 & 0.2724 & 0.0000 & 0.0441 & 3.6202 & 0.0571 & 0.3588 & 0.0000 & 0.0000 & 0.3729 \\
\hline 166 & 1.3529 & 0.0000 & 0.3828 & 23.3448 & 0.0000 & 3.1125 & 0.0000 & 0.0000 & 0.0779 \\
\hline 167 & 1.3492 & 0.0541 & 0.4779 & 20.1541 & 0.0000 & 3.8862 & 0.0023 & 0.0401 & 0.1781 \\
\hline 168 & 0.0000 & 0.0000 & 0.0000 & 0.0000 & 1.0000 & 0.0000 & 0.0000 & 0.0000 & 0.0000 \\
\hline 169 & 0.0000 & 0.0000 & 0.0000 & 0.0000 & 1.0000 & 0.0000 & 0.0000 & 0.0000 & 0.0000 \\
\hline 170 & 0.0000 & 0.0000 & 0.0000 & 0.0000 & 1.0000 & 0.0000 & 0.0000 & 0.0000 & 0.0000 \\
\hline 171 & 2.3512 & 0.0000 & 0.6698 & 30.8621 & 0.0000 & 5.4463 & 0.0000 & 0.0000 & 0.0603 \\
\hline 172 & 1.3529 & 0.0000 & 0.3510 & 23.6433 & 0.0000 & 2.8544 & 0.0000 & 0.0000 & 0.0750 \\
\hline 173 & 0.9159 & 0.0000 & 0.2362 & 16.1752 & 0.0001 & 1.9207 & 0.0000 & 0.0000 & 0.1110 \\
\hline 174 & 2.5514 & 0.0000 & 0.5850 & 39.0254 & 0.0000 & 4.7569 & 0.0000 & 0.0000 & 0.0413 \\
\hline 175 & 0.4238 & 0.0000 & 0.1290 & 7.0778 & 0.0078 & 1.0492 & 0.0000 & 0.0000 & 0.2813 \\
\hline 176 & 3.0000 & 0.0000 & 0.8020 & 50.0929 & 0.0000 & 6.5213 & 0.0000 & 0.0000 & 0.0351 \\
\hline 177 & 0.2903 & 0.0000 & 0.0867 & 4.8037 & 0.0284 & 0.7050 & 0.0000 & 0.0000 & 0.4106 \\
\hline
\end{tabular}


bioRxiv preprint doi: https://doi.org/10.1101/2022.01.21.477254; this version posted January 21, 2022. The copyright holder for this preprint (which was not certified by peer review) is the author/funder, who has granted bioRxiv a license to display the preprint in perpetuity. It is made available under aCC-BY-NC-ND 4.0 International license.

\begin{tabular}{|c|c|c|c|c|c|c|c|c|c|}
\hline 178 & 2.0769 & 0.0000 & 0.7435 & 33.6840 & 0.0000 & 6.0457 & 0.0000 & 0.0000 & 0.0637 \\
\hline 179 & 1.3529 & 0.0000 & 0.2916 & 20.9924 & 0.0000 & 2.3712 & 0.0000 & 0.0000 & 0.0756 \\
\hline 180 & 2.8095 & 0.0000 & 0.5579 & 41.9086 & 0.0000 & 4.5370 & 0.0000 & 0.0000 & 0.0356 \\
\hline 181 & 0.4269 & 0.0000 & 0.1294 & 7.1083 & 0.0077 & 1.0522 & 0.0000 & 0.0000 & 0.2792 \\
\hline 182 & 2.0769 & 0.0000 & 0.5715 & 36.1609 & 0.0000 & 4.6469 & 0.0000 & 0.0000 & 0.0510 \\
\hline 183 & 2.4177 & 0.0000 & 0.7387 & 39.0146 & 0.0000 & 6.0071 & 0.0000 & 0.0000 & 0.0493 \\
\hline 184 & 4.3195 & 0.0699 & 1.0443 & 43.8566 & 0.0000 & 8.4918 & 0.0009 & 0.0162 & 0.0716 \\
\hline 185 & 0.0000 & 0.0000 & 0.0000 & 0.0000 & 1.0000 & 0.0000 & 0.0000 & 0.0000 & 0.0000 \\
\hline 186 & 0.1373 & 0.0000 & 0.0381 & 2.5665 & 0.1092 & 0.3095 & 0.0000 & 0.0000 & 0.7378 \\
\hline 187 & 1.3529 & 0.0000 & 0.3201 & 18.1218 & 0.0000 & 2.6032 & 0.0000 & 0.0000 & 0.0888 \\
\hline 188 & 0.0000 & 0.0000 & 0.0000 & 0.0000 & 1.0000 & 0.0000 & 0.0000 & 0.0000 & 0.0000 \\
\hline 189 & 0.2720 & 0.0000 & 0.0441 & 3.6125 & 0.0573 & 0.3584 & 0.0000 & 0.0000 & 0.3735 \\
\hline 190 & 1.8571 & 0.0000 & 0.3924 & 23.7914 & 0.0000 & 3.1908 & 0.0000 & 0.0000 & 0.0653 \\
\hline 191 & 0.9044 & 0.0000 & 0.1654 & 9.9503 & 0.0016 & 1.3450 & 0.0000 & 0.0000 & 0.1449 \\
\hline 192 & 0.0000 & 0.0000 & 0.0000 & 0.0000 & 1.0000 & 0.0000 & 0.0000 & 0.0000 & 0.0000 \\
\hline 193 & 0.9156 & 0.0000 & 0.1660 & 10.0482 & 0.0015 & 1.3502 & 0.0000 & 0.0000 & 0.1431 \\
\hline 194 & 0.2724 & 0.0000 & 0.0451 & 3.5786 & 0.0585 & 0.3665 & 0.0000 & 0.0000 & 0.3827 \\
\hline
\end{tabular}


bioRxiv preprint doi: https://doi.org/10.1101/2022.01.21.477254; this version posted January 21, 2022. The copyright holder for this preprint (which was not certified by peer review) is the author/funder, who has granted bioRxiv a license to display the preprint in perpetuity. It is made available under aCC-BY-NC-ND 4.0 International license.

\begin{tabular}{|c|c|c|c|c|c|c|c|c|c|}
\hline 195 & 0.1373 & 0.0000 & 0.0392 & 2.5100 & 0.1131 & 0.3184 & 0.0000 & 0.0000 & 0.7677 \\
\hline 196 & 0.8673 & 0.0531 & 0.1785 & 6.8492 & 0.0089 & 1.4516 & 0.0035 & 0.0612 & 0.2703 \\
\hline 197 & 0.6237 & 0.0000 & 0.0904 & 7.7740 & 0.0053 & 0.7354 & 0.0000 & 0.0000 & 0.1619 \\
\hline 198 & 0.7734 & 0.0000 & 0.1617 & 12.4902 & 0.0004 & 1.3145 & 0.0000 & 0.0000 & 0.1260 \\
\hline 199 & 0.9136 & 0.0000 & 0.2416 & 15.6381 & 0.0001 & 1.9647 & 0.0000 & 0.0000 & 0.1160 \\
\hline 200 & 0.0000 & 0.0439 & 0.0439 & 0.0088 & 0.9254 & 0.3566 & 1462.1862 & $\begin{array}{c}10000.000 \\
0\end{array}$ & $\begin{array}{c}10000.000 \\
0\end{array}$ \\
\hline 201 & 0.8954 & 0.0000 & 0.2625 & 17.0957 & 0.0000 & 2.1349 & 0.0000 & 0.0000 & 0.1132 \\
\hline 202 & 0.5743 & 0.0690 & 0.1664 & 3.1111 & 0.0778 & 1.3533 & 0.0068 & 0.1202 & 0.5326 \\
\hline 203 & 3.0000 & 0.0000 & 0.8142 & 50.6222 & 0.0000 & 6.6207 & 0.0000 & 0.0000 & 0.0351 \\
\hline 204 & 0.4000 & 0.0000 & 0.0825 & 6.2389 & 0.0125 & 0.6712 & 0.0000 & 0.0000 & 0.2512 \\
\hline 205 & 1.2072 & 0.0537 & 0.2628 & 11.6100 & 0.0007 & 2.1373 & 0.0025 & 0.0445 & 0.1973 \\
\hline 206 & 1.3529 & 0.0000 & 0.3132 & 21.2564 & 0.0000 & 2.5470 & 0.0000 & 0.0000 & 0.0750 \\
\hline 207 & 0.2877 & 0.0000 & 0.0444 & 3.7112 & 0.0540 & 0.3610 & 0.0000 & 0.0000 & 0.3519 \\
\hline 208 & 2.6056 & 0.0000 & 0.5748 & 39.9407 & 0.0000 & 4.6744 & 0.0000 & 0.0000 & 0.0376 \\
\hline 209 & 0.5731 & 0.0000 & 0.1538 & 10.3900 & 0.0013 & 1.2509 & 0.0000 & 0.0000 & 0.1770 \\
\hline 210 & 0.5502 & 0.0000 & 0.0759 & 7.9203 & 0.0049 & 0.6170 & 0.0000 & 0.0000 & 0.1531 \\
\hline 211 & 0.0000 & 0.0000 & 0.0000 & 0.0000 & 1.0000 & 0.0000 & 0.0000 & 0.0000 & 0.0000 \\
\hline
\end{tabular}


bioRxiv preprint doi: https://doi.org/10.1101/2022.01.21.477254; this version posted January 21, 2022. The copyright holder for this preprint (which was not certified by peer review) is the author/funder, who has granted bioRxiv a license to display the preprint in perpetuity. It is made available under aCC-BY-NC-ND 4.0 International license.

\begin{tabular}{|c|c|c|c|c|c|c|c|c|c|}
\hline 212 & 1.6439 & 0.0000 & 0.3321 & 24.7877 & 0.0000 & 2.7006 & 0.0000 & 0.0000 & 0.0609 \\
\hline 213 & 0.3655 & 0.1001 & 0.1571 & 1.5333 & 0.2156 & 1.2773 & 0.0454 & 0.2740 & 0.8525 \\
\hline 214 & 4.5596 & 0.0000 & 0.6112 & 53.3306 & 0.0000 & 4.9697 & 0.0000 & 0.0000 & 0.0213 \\
\hline 215 & 0.0000 & 0.0000 & 0.0000 & 0.0000 & 1.0000 & 0.0000 & 0.0000 & 0.0000 & 0.0000 \\
\hline 216 & 1.8153 & 0.0000 & 0.2159 & 20.6059 & 0.0000 & 1.7556 & 0.0000 & 0.0000 & 0.0522 \\
\hline 217 & 0.9243 & 0.0000 & 0.2666 & 14.5720 & 0.0001 & 2.1675 & 0.0000 & 0.0000 & 0.1312 \\
\hline 218 & 2.0769 & 0.0000 & 0.3184 & 21.3914 & 0.0000 & 2.5891 & 0.0000 & 0.0000 & 0.0590 \\
\hline 219 & 0.6452 & 0.0000 & 0.0910 & 7.8870 & 0.0050 & 0.7397 & 0.0000 & 0.0000 & 0.1567 \\
\hline 220 & 0.0928 & 0.0000 & 0.0395 & 1.1939 & 0.2746 & 0.3210 & 0.0000 & 0.0000 & 1.7623 \\
\hline 221 & 0.0000 & 0.0000 & 0.0000 & 0.0000 & 1.0000 & 0.0000 & 0.0000 & 0.0000 & 0.0000 \\
\hline 222 & 0.2835 & 0.0000 & 0.0789 & 5.0825 & 0.0242 & 0.6414 & 0.0000 & 0.0000 & 0.3719 \\
\hline 223 & 2.3567 & 0.0000 & 0.3682 & 24.3183 & 0.0000 & 2.9942 & 0.0000 & 0.0000 & 0.0521 \\
\hline 224 & 1.6066 & 0.0000 & 0.4605 & 22.0347 & 0.0000 & 3.7447 & 0.0000 & 0.0000 & 0.0858 \\
\hline 225 & 11.2648 & 0.0000 & 1.0274 & 68.4271 & 0.0000 & 8.3540 & 0.0000 & 0.0000 & 0.0116 \\
\hline 226 & 0.7404 & 0.0000 & 0.2181 & 12.0620 & 0.0005 & 1.7737 & 0.0000 & 0.0000 & 0.1610 \\
\hline 227 & 0.1729 & 0.0000 & 0.0784 & 3.7735 & 0.0521 & 0.6379 & 0.0000 & 0.0000 & 0.7082 \\
\hline 228 & 1.7586 & 0.0000 & 0.4540 & 30.8744 & 0.0000 & 3.6920 & 0.0000 & 0.0000 & 0.0593 \\
\hline
\end{tabular}


bioRxiv preprint doi: https://doi.org/10.1101/2022.01.21.477254; this version posted January 21, 2022. The copyright holder for this preprint (which was not certified by peer review) is the author/funder, who has granted bioRxiv a license to display the preprint in perpetuity. It is made available under aCC-BY-NC-ND 4.0 International license.

\begin{tabular}{|c|c|c|c|c|c|c|c|c|c|}
\hline 229 & 2.3195 & 0.0000 & 0.6722 & 35.6279 & 0.0000 & 5.4661 & 0.0000 & 0.0000 & 0.0530 \\
\hline 230 & 0.4314 & 0.0000 & 0.1189 & 7.6758 & 0.0056 & 0.9671 & 0.0000 & 0.0000 & 0.2444 \\
\hline 231 & 0.0000 & 0.0000 & 0.0000 & 0.0000 & 1.0000 & 0.0000 & 0.0000 & 0.0000 & 0.0000 \\
\hline 232 & 0.0000 & 0.0000 & 0.0000 & 0.0000 & 1.0000 & 0.0000 & 0.0000 & 0.0000 & 0.0000 \\
\hline 233 & 0.5711 & 0.1372 & 0.1973 & 2.0310 & 0.1541 & 1.6047 & 0.0597 & 0.2403 & 0.6289 \\
\hline 234 & 0.0000 & 0.0000 & 0.0000 & 0.0000 & 1.0000 & 0.0000 & 0.0000 & 0.0000 & 0.0000 \\
\hline 235 & 0.2636 & 0.0000 & 0.0440 & 3.5732 & 0.0587 & 0.3576 & 0.0000 & 0.0000 & 0.3853 \\
\hline 236 & 2.6511 & 0.0000 & 0.7753 & 46.0604 & 0.0000 & 6.3044 & 0.0000 & 0.0000 & 0.0390 \\
\hline 237 & 1.0663 & 0.0560 & 0.3290 & 12.7008 & 0.0004 & 2.6757 & 0.0030 & 0.0525 & 0.2331 \\
\hline 238 & 0.6357 & 0.0000 & 0.1581 & 11.0293 & 0.0009 & 1.2852 & 0.0000 & 0.0000 & 0.1594 \\
\hline 239 & 0.0000 & 0.0000 & 0.0000 & 0.0000 & 1.0000 & 0.0000 & 0.0000 & 0.0000 & 0.0000 \\
\hline 240 & 2.0993 & 0.0000 & 0.8145 & 34.8044 & 0.0000 & 6.6232 & 0.0000 & 0.0000 & 0.0635 \\
\hline 241 & 0.6014 & 0.0000 & 0.0939 & 7.3236 & 0.0068 & 0.7636 & 0.0000 & 0.0000 & 0.1788 \\
\hline 242 & 1.3529 & 0.0000 & 0.1970 & 20.0704 & 0.0000 & 1.6019 & 0.0000 & 0.0000 & 0.0637 \\
\hline 243 & 0.4994 & 0.0000 & 0.1160 & 8.6482 & 0.0033 & 0.9429 & 0.0000 & 0.0000 & 0.1943 \\
\hline 244 & 0.0000 & 0.0000 & 0.0000 & 0.0000 & 1.0000 & 0.0000 & 0.0000 & 0.0000 & 0.0000 \\
\hline 245 & 0.0000 & 0.0000 & 0.0000 & 0.0000 & 1.0000 & 0.0000 & 0.0000 & 0.0000 & 0.0000 \\
\hline
\end{tabular}


bioRxiv preprint doi: https://doi.org/10.1101/2022.01.21.477254; this version posted January 21, 2022. The copyright holder for this preprint (which was not certified by peer review) is the author/funder, who has granted bioRxiv a license to display the preprint in perpetuity. It is made available under aCC-BY-NC-ND 4.0 International license.

\begin{tabular}{|c|c|c|c|c|c|c|c|c|c|}
\hline 246 & 0.0928 & 0.0000 & 0.0366 & 2.1737 & 0.1404 & 0.2972 & 0.0000 & 0.0000 & 1.1363 \\
\hline 247 & 0.7803 & 0.0000 & 0.2206 & 12.6274 & 0.0004 & 1.7937 & 0.0000 & 0.0000 & 0.1503 \\
\hline 248 & 0.1649 & 0.0000 & 0.0395 & 2.8905 & 0.0891 & 0.3211 & 0.0000 & 0.0000 & 0.6024 \\
\hline 249 & 1.0218 & 0.1248 & 0.4662 & 10.2373 & 0.0014 & 3.7913 & 0.0202 & 0.1222 & 0.3798 \\
\hline 250 & 0.0000 & 0.0000 & 0.0000 & 0.0000 & 1.0000 & 0.0000 & 0.0000 & 0.0000 & 0.0000 \\
\hline 251 & 0.0000 & 0.0000 & 0.0000 & 0.0000 & 1.0000 & 0.0000 & 0.0000 & 0.0000 & 0.0000 \\
\hline 252 & 0.0000 & 0.0000 & 0.0000 & 0.0000 & 1.0000 & 0.0000 & 0.0000 & 0.0000 & 0.0000 \\
\hline 253 & 0.1668 & 0.0000 & 0.0394 & 2.8836 & 0.0895 & 0.3208 & 0.0000 & 0.0000 & 0.5956 \\
\hline 254 & 0.2793 & 0.1183 & 0.1771 & 0.8135 & 0.3671 & 1.4401 & 0.0704 & 0.4234 & 1.3076 \\
\hline 255 & 1.2093 & 0.0823 & 0.5111 & 11.5180 & 0.0007 & 4.1560 & 0.0039 & 0.0680 & 0.3022 \\
\hline 256 & 0.1388 & 0.0000 & 0.0395 & 2.5133 & 0.1129 & 0.3213 & 0.0000 & 0.0000 & 0.7658 \\
\hline 257 & 0.0000 & 0.0000 & 0.0000 & 0.0000 & 1.0000 & 0.0000 & 0.0000 & 0.0000 & 0.0000 \\
\hline 258 & 1.9630 & 0.0000 & 0.4167 & 30.3846 & 0.0000 & 3.3887 & 0.0000 & 0.0000 & 0.0513 \\
\hline 259 & 0.9679 & 0.0000 & 0.2005 & 15.4029 & 0.0001 & 1.6302 & 0.0000 & 0.0000 & 0.1003 \\
\hline 260 & 0.2929 & 0.0000 & 0.1083 & 5.9411 & 0.0148 & 0.8807 & 0.0000 & 0.0000 & 0.3766 \\
\hline 261 & 0.1136 & 0.0508 & 0.0703 & 0.3166 & 0.5737 & 0.5720 & 0.0255 & 0.4468 & 1.9804 \\
\hline
\end{tabular}

These results are also available at the following link:

https://github.com/aglucaci/AnalysisOfOrthologousCollections/blob/main/tables/BDNF/BDNF F EL Cl.csv 